\title{
Year-Round Irrigation Schedule for a Tomato-Maize Rotation System in Reservoir-Based Irrigation Schemes in Ghana
}

\author{
Ephraim Sekyi-Annan ${ }^{1,2}$, Bernhard Tischbein ${ }^{1}$, Bernd Diekkrüger ${ }^{3}$ (D) and Asia Khamzina ${ }^{4, *}$ (iD \\ 1 Department of Ecology and Natural Resources Management, Center for Development Research, \\ University of Bonn, Genscherallee 3, 53113 Bonn, Germany; sekyiannan@yahoo.com (E.S.-A.); \\ tischbein@uni-bonn.de (B.T.) \\ 2 CSIR-Soil Research Institute, Academy Post Office, Private Mail Bag, Kwadaso-Kumasi, Ghana; \\ sekyiannan@yahoo.com \\ 3 Department of Geography, University of Bonn, Meckenheimer Allee 166, 53115 Bonn, Germany; \\ b.diekkrueger@uni-bonn.de \\ 4 Division of Environmental Science and Ecological Engineering, College of Life Science and Biotechnology, \\ Korea University, 145 Anam-Ro, Seongbuk-Gu, Seoul 02841, Korea \\ * Correspondence: asia_khamzina@korea.ac.kr; Tel.: +82-2-3290-3062
}

Received: 23 March 2018; Accepted: 8 May 2018; Published: 10 May 2018

\begin{abstract}
Improving irrigation management in semi-arid regions of Sub-Saharan Africa is crucial to respond to increasing variability in rainfall and overcome deficits in current irrigation schemes. In small-scale and medium-scale reservoir-based irrigation schemes in the Upper East region of Ghana, we explored options for improving the traditional, dry season irrigation practices and assessed the potential for supplemental irrigation in the rainy season. The AquaCrop model was used to (i) assess current water management in the typical tomato-maize rotational system; (ii) develop an improved irrigation schedule for dry season cultivation of tomato; and (iii) determine the requirement for supplemental irrigation of maize in the rainy season under different climate scenarios. The improved irrigation schedule for dry season tomato cultivation would result in a water saving of 130-1325 mm compared to traditional irrigation practices, accompanied by approximately a $4-14 \%$ increase in tomato yield. The supplemental irrigation of maize would require $107-126 \mathrm{~mm}$ of water in periods of low rainfall and frequent dry spells, and $88-105 \mathrm{~mm}$ in periods of high rainfall and rare dry spells. Therefore, year-round irrigated crop production may be feasible, using water saved during dry season tomato cultivation for supplemental irrigation of maize in the rainy season.
\end{abstract}

Keywords: AquaCrop model; capillary rise; climate change; rainfall variability; supplemental irrigation

\section{Introduction}

Insufficient water availability, owing to variability in rainfall patterns and frequent dry spells exacerbated by climate change [1,2], threatens food security and rural livelihoods in Sub-Saharan Africa (SSA) [3]. In SSA, more than $95 \%$ of arable land is under rainfed crop production, which contributes $81 \%$ to the regional food basket [4,5]. Because of variable rainfall and low-input cultivation [6,7], grain yields are only from 1 to $2 \mathrm{Mg} \mathrm{ha}^{-1}$, whereas attainable yields range between 4 and $5 \mathrm{Mg} \mathrm{ha}^{-1}$ in SSA [5,8]. Furthermore, risks of crop failure in SSA have increased due to land degradation and soil nutrient depletion $[9,10]$, signified by negative annual NPK balances with $-26 \mathrm{~kg} \mathrm{ha}^{-1} \mathrm{~N},-7 \mathrm{~kg} \mathrm{ha}^{-1}$ $\mathrm{P}_{2} \mathrm{O}_{5}$, and $-23 \mathrm{~kg} \mathrm{ha}^{-1} \mathrm{~K}_{2} \mathrm{O}$, as reported in [11]. On a continental scale, annual NPK losses averaged $54 \mathrm{~kg} \mathrm{ha}^{-1}$ (and ranged between $9 \mathrm{~kg} \mathrm{ha}^{-1}$ in Egypt and $88 \mathrm{~kg} \mathrm{ha}^{-1}$ in Somalia), resulting in land degradation in more than $40 \%$ of Africa's total farmland [12,13]. These risks have further reduced 
the already insufficient financial capacity of farmers to invest in sustainable land management (SLM) strategies [3,5]. However, such strategies are key for optimizing trade-offs between food production and other agro-ecosystem services [12]. In water-scarce environments such as the Upper East region of Ghana (UER), sustainable soil-water management has been identified as the most influential among agricultural management practices, including soil fertility management, selection of crop varieties, and control of pests and diseases $[5,14]$, for enhancing food security as well as improving the smallholders' livelihoods [5,15-17].

The reservoir-based irrigation schemes in SSA, which store water (i.e., mostly surface runoff) in the rainy season, were originally designed to supply water for dry season crop irrigation, the livestock sector, fish farming, and domestic use, excluding supplemental irrigation in the rainy season. However, increasing climate variability calls for exploring the feasibility of supplemental irrigation for crop cultivation in the rainy season [3]. Supplemental irrigation has considerable potential to increase grain yield, particularly if provided during the critical stages of the crop growing cycle (i.e., booting and grain filling) [18].

Because of increasing competition for stored water in the dry season, the extra water demand for supplemental irrigation to bridge dry spells is likely to result in a mismatch between water supply and demand in the reservoir-based irrigation schemes. Thus, the requirement for supplemental irrigation might be satisfied with water saved through increased irrigation efficiency as a result of improving dry season irrigation scheduling [19]. As long as increased irrigation efficiency is accompanied by yield increments, this provides incentives for irrigators to engage in SLM $[5,15,18,20]$. Consequently, crop-water-soil-atmosphere models will be useful to determine the most appropriate irrigation schedules for the prevalent cropping practices and for assessing possible alternative scenarios [21-23]. Among the common models capable of simulating irrigated crop growth, those requiring large inputs of primary data, for instance APSIM [24] and CropSyst [25], and that are not available for free, such as the irrigation scheduling model ISAREG [26], might not be favorable for applications in SSA. The DSSAT model [27] has been commonly used to assess the impact of agronomic inputs on irrigated crop yield but at present is not suitable to evaluate the effectiveness of irrigation practices. Some other models, such as CROPWAT [28] do not distinguish between evaporation (i.e., non-beneficial water consumption) and crop transpiration, and do not provide an estimation of yield or, as with EPIC [29], apply simplified routines to evaluate the groundwater contribution to crop water use. Due to relatively modest data requirements, consideration of all major agro-hydrological processes, and its free availability, the AquaCrop model developed by the Food and Agriculture Organization of the Unites Nations (FAO) [22] has found many applications worldwide, including in SSA [30-32].

Current irrigation schedules in reservoir-based irrigation schemes in SSA are based on locally established rules governing access to water for irrigation, but with little consideration of crop- and site-specific water demands in terms of quantity and timing, resulting in the over-irrigation of crops [19]. For instance, in reservoir-based irrigation schemes in onion fields in the UER, the ratio of total water supply to gross irrigation demand ranged between 2.4 and 5.7 during dry season crop irrigation [33]. The problem of over-irrigation in reservoir-based irrigation schemes was further confirmed by gross irrigation amounts (GIAs) ranging from 380 to $852 \mathrm{~mm}$ for dry season tomato production in the UER [34], and between 274 and $838 \mathrm{~mm}$ for tomato cropping under groundwater irrigation in the same region [35]. Simulations have suggested that the net irrigation requirement (NIR) for dry season tomatoes ranges from 359 to $372 \mathrm{~mm}$ in the reservoir-based Koga irrigation scheme in Ethiopia [36], emphasizing the need as well as the potential to improve water management through irrigation scheduling to reduce water losses and increase productivity.

To the best of our knowledge, no study has attempted to develop an irrigation schedule for dry season cropping systems in the UER. Moreover, the limited number of studies on supplemental irrigation in SSA have not explored the feasibility of using dry season water savings in reservoir-based irrigation schemes. For example, Sanfo et al. [3] investigated the economic value of supplemental irrigation of grain crops using farm ponds of $300 \mathrm{~m}^{3}$ capacity in south-western Burkina Faso, and 
reported that in years of low rainfall, supplemental irrigation could be a cost-effective intervention to reduce risks of crop failure and increase farmers' incomes. Fox and Rockström [37] also assessed the effect of supplemental irrigation, based on $150 \mathrm{~m}^{3}$ capacity farm ponds, on the grain yield of sorghum in northern Burkina Faso and found that supplemental irrigation alone resulted in an approximately $56 \%$ increase in grain yield, making it a useful technology to mitigate dry spells and shorten the yield gap. Similarly, Mustapha [16] studied the water productivity of pearl millet under supplemental irrigation applied at five different crop growth stages in Nigeria and reported that the supplemental irrigation amount of $84 \mathrm{~mm}$ applied at booting and grain filling stages could result in a $69 \%$ increase in yields.

This study aims to improve the traditional dry season irrigation practices in reservoir-based irrigation schemes in the UER, and to assess the potential for introducing supplemental irrigation in the rainy season as an adaptation to climate change. To this end, we (i) parameterized and validated the AquaCrop model to render applications for irrigated crop production in the EUR of Ghana (ii) assessed the appropriateness of current water management in the typical tomato-maize rotational system; (iii) developed an improved irrigation schedule for dry season cultivation of tomato; and (iv) determined the requirement for supplemental irrigation of maize in the rainy season under different climate scenarios.

\section{Materials and Methods}

\subsection{Study Area}

The study was conducted between May 2014 and April 2016 in the medium-scale Vea irrigation scheme (VIS, $136 \mathrm{~km}^{2}$ ) and the small-scale Bongo irrigation scheme (BIS, $0.98 \mathrm{~km}^{2}$ ) in the UER, located between latitudes $10^{\circ} 30^{\prime} \mathrm{N}$ and $11^{\circ} 15^{\prime} \mathrm{N}$ and longitudes $0^{\circ} \mathrm{W}$ and $1^{\circ} 30^{\prime} \mathrm{W}$ (Figure 1). The UER belongs to the Guinea-Sudano-Savanna agro-ecological zone characterized by a single rainy season starting in April/May and ending in September/October, followed by a dry season from November until April/May. The mean annual rainfall is $970 \mathrm{~mm}$ with high intra- and inter-seasonal variability, and the mean annual temperature is $29^{\circ} \mathrm{C}$ (Figure 2). The annual potential evapotranspiration $\left(\mathrm{ET}_{0}\right)$ is twice as much as the annual precipitation, but evapotranspiration is exceeded by rainfall in the rainy season [34]. Soil types in the UER include Gleyic Lixisols, Ferric Lixisols, Haplic Lixisols, Lithic Leptosols, and Eutric Fluvisols, with loam and sandy loam as the dominating soil textures.

Two schemes were selected to capture the typical scale of irrigation schemes in the region, as well as the differing institutional settings in operations by the parastatal Irrigation Company of the Upper Region (ICOUR, Navrongo, Ghana) in Vea, and a community-based operation in Bongo (Figure 1). Furthermore, water allocation in the VIS is supply-driven, and thus a technician implements water supply schedules for $4-5$ days continuously with 3-4 days interval between schedules. However, in the BIS, where water allocation is demand-driven, water can flow for the whole week $(8 \mathrm{~h}$ per day on average) except on market days which occur twice a week. Irrigators in the UER tend to water their crops with as much water as is available resulting in over-irrigation, hence there is an urgent need for improved schedules which are crop- and site-specific [19]. On average, the total irrigation events for the dry season production of tomato ranges between 20 and 29 in both VIS and BIS.

The storage capacity, the elevation of the reservoir's spillway, and the irrigable area of the BIS are $0.43 \mathrm{MCM}, 231 \mathrm{~m}$ and 12 ha, respectively, while the values for the VIS are $17.27 \mathrm{MCM}, 189 \mathrm{~m}$ and 850 ha, respectively. The irrigable area in both schemes is equipped with lined trapezoidal primary canals which convey water by gravity to the cropping fields. Farm sizes range between 0.01 and 0.10 ha in the dry season, and up to 0.31 ha in the rainy season, in both irrigation schemes.

Rainfed crops include maize (Zea mays), pearl millet (Pennisetum glaucum), sorghum (Sorghum bicolor), and rice (Oryza sativa; cultivated also in the dry season under irrigation). Tomato (Solanum lycopersicum) and leafy vegetables such as roselle (Hibiscus sabdariffa), lettuce (Latuca sativa) and cowpea (Vigna unguiculata; grown primarily for the leaves) are irrigated in the dry season only. 
Currently, irrigation is not practiced in the rainy season. There are no soil bunds constructed on the cropping fields, except around rice fields. Furthermore, furrows are not blocked during irrigation, resulting in the surface runoff of irrigation water.

(b)

(a)

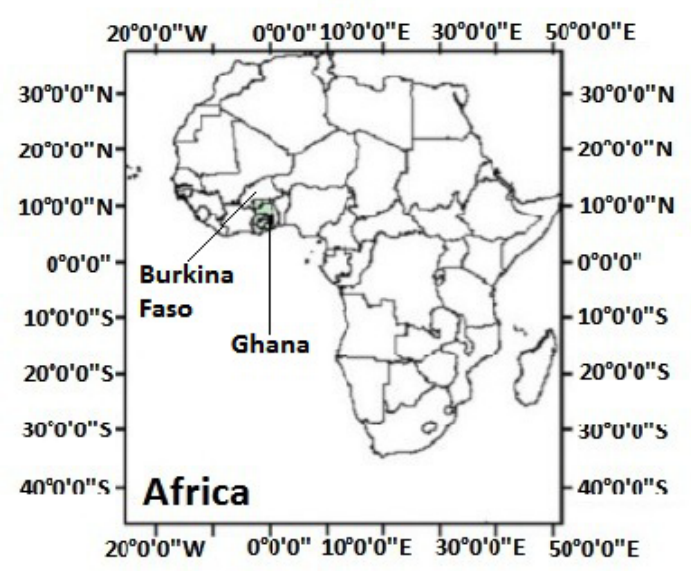

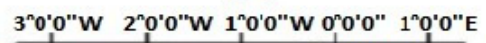

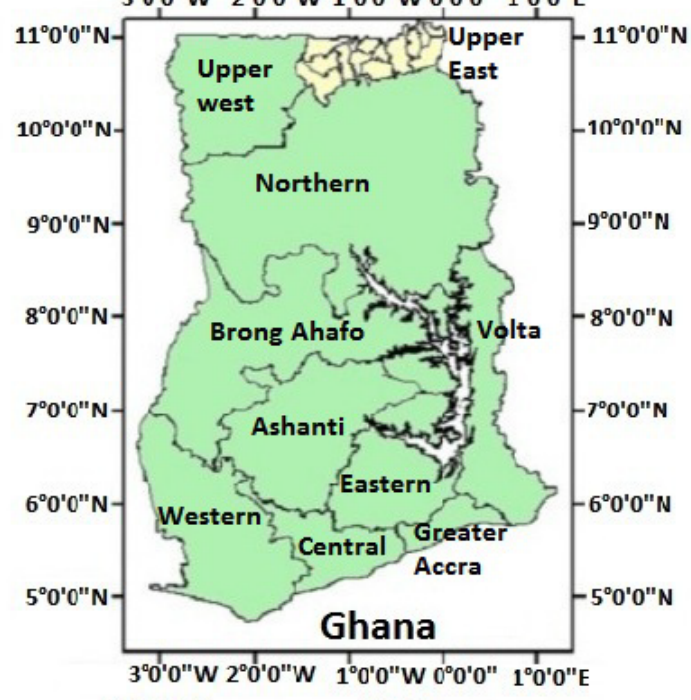

$0^{\circ} 30^{\prime} 0 " W \quad 0^{\circ} 0^{\prime} 0^{\prime \prime}$

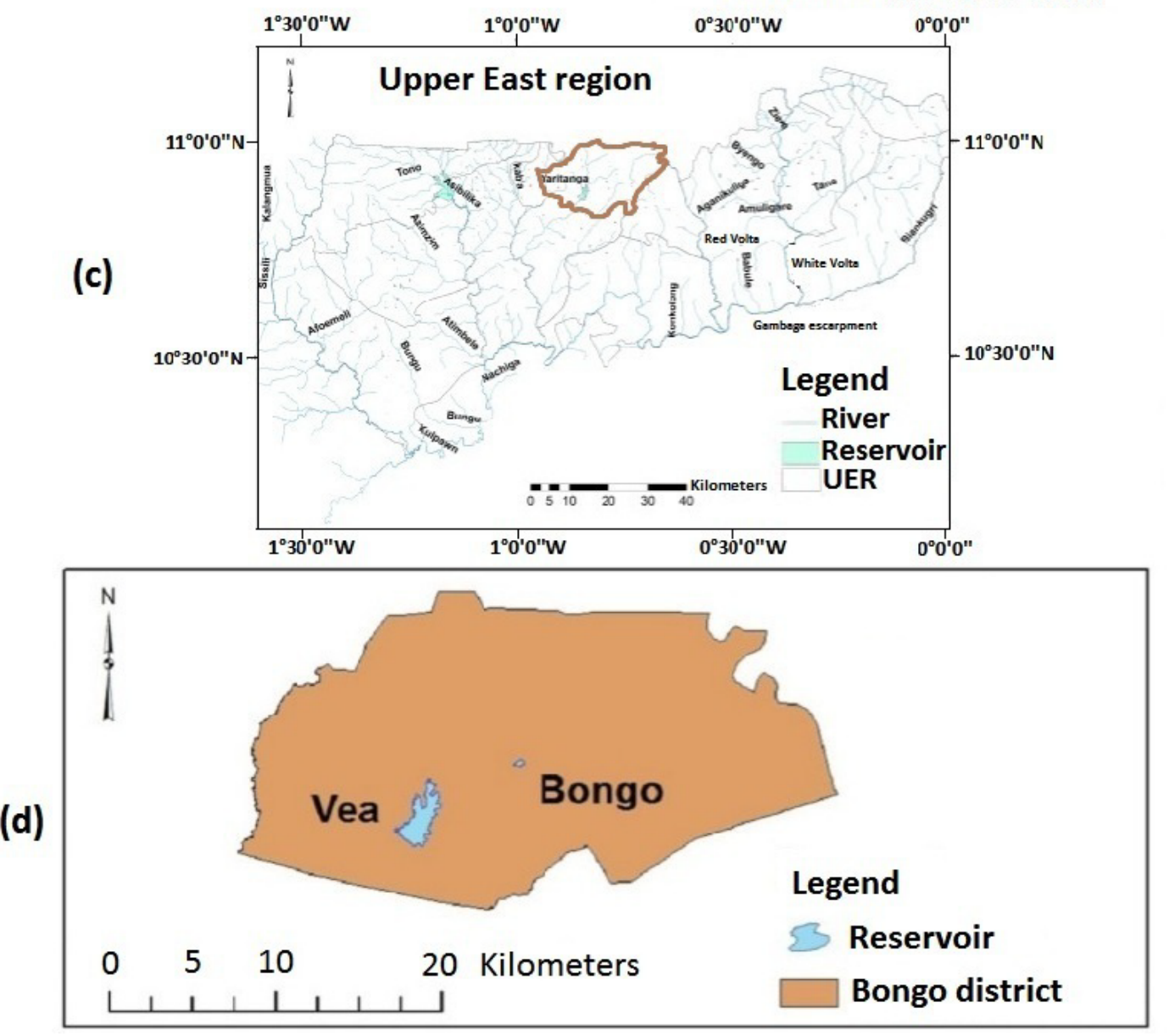

Figure 1. Location of Ghana in West Africa (a); the Upper East region (UER) of Ghana (b); hydrological network of the UER and location of the study area (c); and the study area including the Vea and Bongo reservoirs (d). 


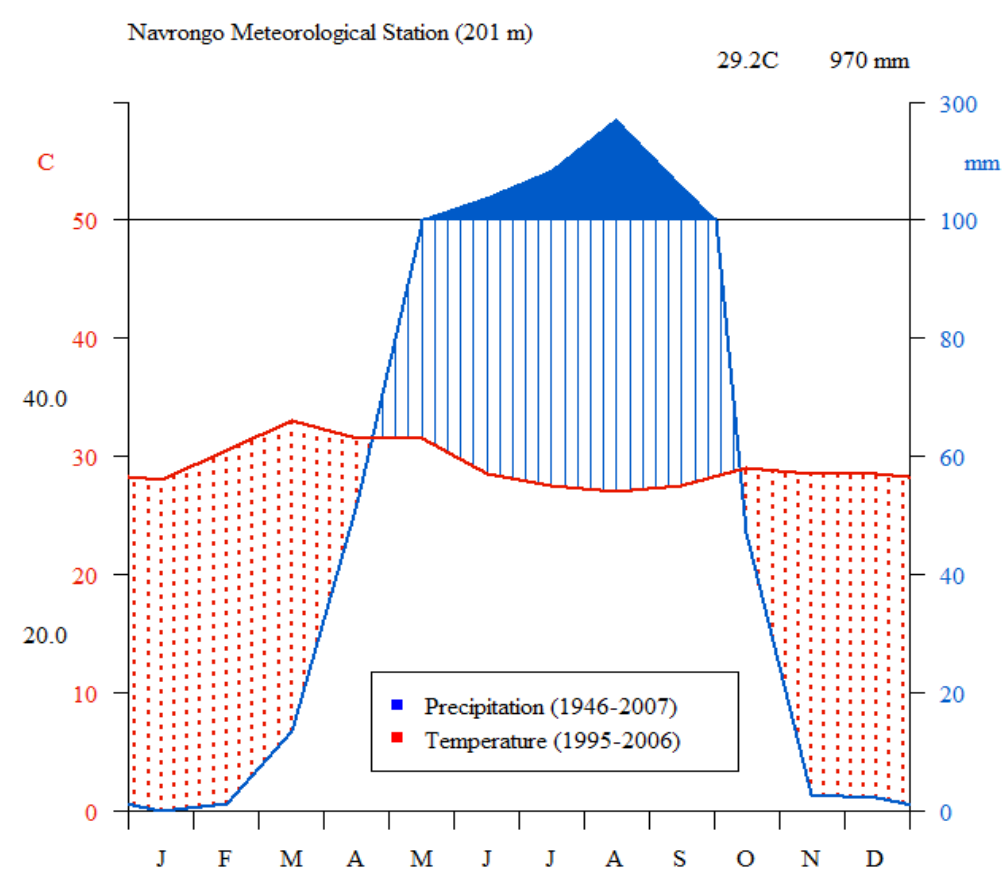

Figure 2. Walter-Lieth climate diagram for the Upper East region of Ghana based on data collected at Navrongo Meteorological Station (latitude $10^{\circ} 54^{\prime} 0^{\prime \prime} \mathrm{N}$ and longitude $1^{\circ} 06^{\prime} 0^{\prime \prime} \mathrm{W}$; elevation $201 \mathrm{~m}$ above sea level). Precipitation data covered the period 1946-2007, and temperature data were measured between 1995 and 2006. Top of the graph shows the long-term mean annual temperature and rainfall. The value at the top-left of the temperature axis is the mean of the average daily maximum temperature of the hottest month; the value at the bottom of the same axis is the mean of the average daily minimum temperature of the coldest month. Area shaded in blue indicates the moist period and area shaded in red show the arid period. Area filled in blue indicates the period of excess water.

The principal cropping systems include tomato-maize rotation, millet/sorghum-leafy vegetable rotation, and rice mono-cropping under alternate wet-dry irrigation. In the VIS, the shares of the irrigable area in the dry season were $48 \%, 37 \%$, and $12 \%$ for tomato, rice, and leafy vegetables, respectively, and $40 \%, 5 \%$, and $55 \%$ for the same crops in the BIS. In the rainy season, the shares were $50 \%, 40 \%$, and $10 \%$ for millet/sorghum, rice, and maize, respectively, in the BIS, while in the VIS these shares were $34 \%, 59 \%$ and $3 \%$. In this study, the cropping system of dry season irrigated tomato in rotation with maize in the rainy season was selected for detailed analysis due to the socio-economic significance of these crops in the UER and SSA. Tomato was cropped once in the dry season in both the BIS and the VIS. The growing and irrigation period lasted for 113-123 days. In this period, mature tomato fruits were harvested 2-3 times. The duration of tomato seedling development was about 14 days. The growing period of maize sown directly in the field ranged between 84 and 113 days.

The application of cow manure $\left(1 \mathrm{Mg} \mathrm{ha}^{-1}\right)$, NPK $\left(0.21-0.7 \mathrm{Mg} \mathrm{ha}^{-1}\right)$ and ammonium sulfate fertilizer (0.1-0.34 Mg ha ${ }^{-1}$ ) for tomato and maize, and Karate (i.e., lambda-cyhalothrin) and DDT insecticides for tomato only was observed in both schemes. On maize fields, manure was applied at ploughing, and mineral fertilizer at a later growth stage. Insufficient application of mineral fertilizer is common due to the high cost involved $[9,38]$. The fertilizers were applied twice in tomato and maize fields at $2-3$ weeks after planting and later at $4-5$ weeks after planting.

\subsection{Model Description}

AquaCrop is a crop water productivity model that simulates the response of crop yield to water supply and is particularly useful where water limits crop production. The model runs in daily time-steps which provides the basis for investigating the appropriateness of irrigation schedules 
to meet crop-specific demands in practical scheme operation. Consequently, the AquaCrop-based schedules have a high potential to increase crop water productivity [22]. The AquaCrop model can also simulate the effect of climate variability (including variations in temperature, atmospheric carbon dioxide and available water/rainfall) on crop production [22]. Additional useful features of the model are the ability to separate soil evaporation from crop transpiration and to quantify the capillary rise from shallow groundwater.

\subsection{Data Collection and Preparation}

The input data required for running AquaCrop were collected from two fields under a tomato-maize rotation system in each irrigation scheme (Figure 3).

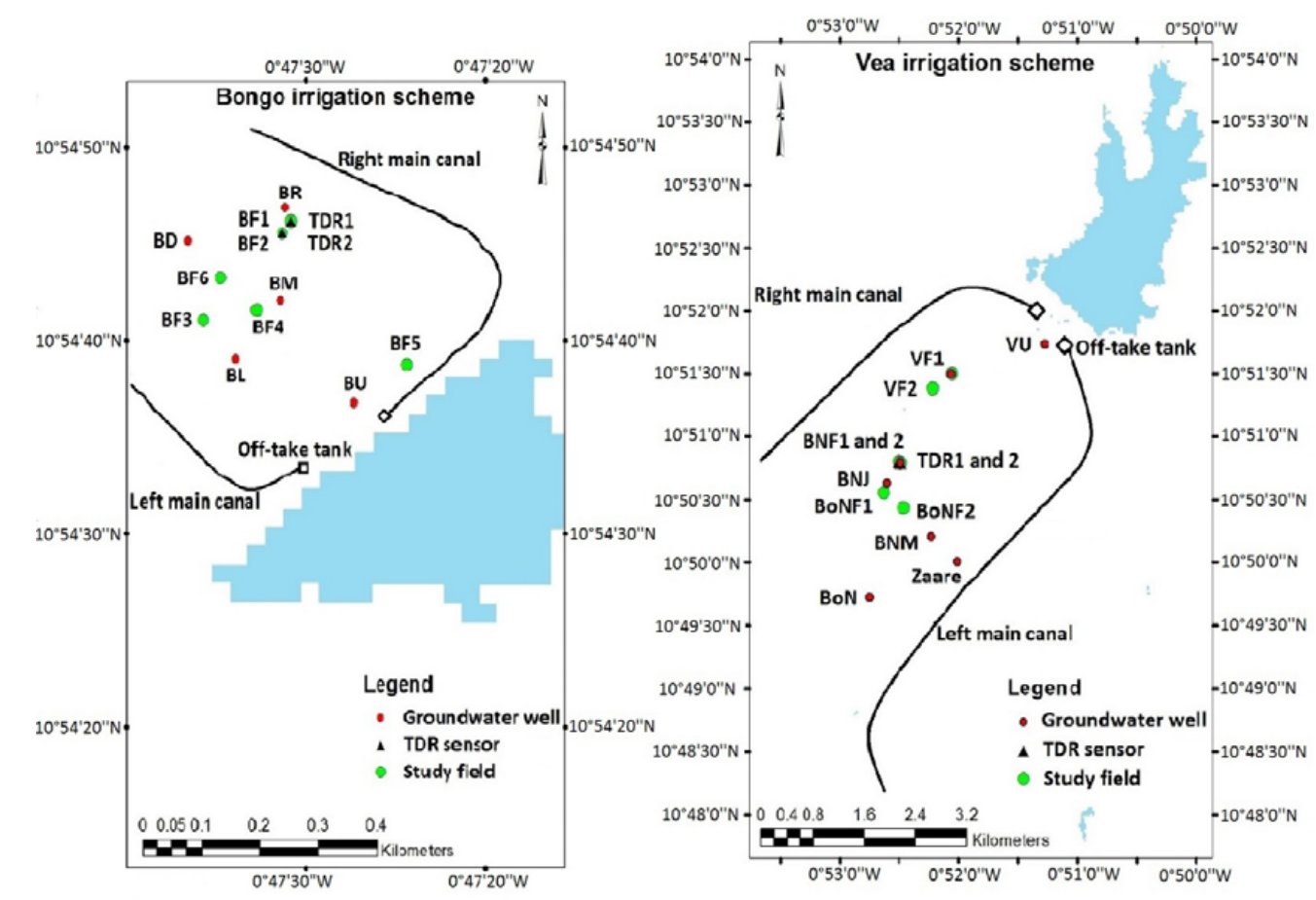

Figure 3. Layout of the irrigation schemes (reproduced from Sekyi-Annan et al. [19]). BF1-6 = Bongo fields, BNF1, 2 = Bongo Nyariga fields, BoNF1, 2 = Bolga Nyariga fields, BR = Bongo right well, $\mathrm{BL}=$ Bongo left well, $\mathrm{BM}=$ Bongo middle well, $\mathrm{BD}=$ Bongo downslope well, $\mathrm{BU}=$ Bongo upslope well, VF1, 2 = Vea fields, VU = Vea upslope well, BNM = Bongo Nyariga middle well, BNJ = Bongo Nyariga junction well, TDR1, 2 = Time domain reflectometers.

The model performance, based on the simulation of aboveground dry matter (DM), was assessed with multiple inbuilt statistical indicators including the coefficient of determination $\left(R^{2}\right)$, normalized root mean square error (NRMSE), Nash-Sutcliffe model efficiency coefficient (EF), and Willmott's index of agreement (d). The $R^{2}$ indicates the fraction of the variance in observed data explained by the model and ranges from 0 (no agreement) to 1 (perfect agreement) between simulated and observed data. Typically, $\mathrm{R}^{2}>0.5$ is acceptable for watershed simulations [39]. The NRMSE signifies the relative difference between the simulated results and the measured data, with NRMSE $<10 \%, 10-20 \%, 20-30 \%$, and $>30 \%$ showing excellent, good, fair, and poor model performance, respectively. The EF quantifies the relative magnitude of the residual variance in comparison to the variance of the observed data. EF ranges between 1 and $-\infty$, where 1 signifies a perfect match between predictions and observations, 0 indicates that predictions are as accurate as the observed means, and a negative value indicates poor predictability. The $\mathrm{d}$ quantifies the extent to which the measured data are approached by the predictions and ranges from 0 (no agreement) to 1 (perfect agreement). 


\subsubsection{Estimation of Potential Evapotranspiration and Net Irrigation Requirement}

Maximum and minimum air temperatures $\left(\mathrm{T}_{\max }\right.$ and $\left.\mathrm{T}_{\min },{ }^{\circ} \mathrm{C}\right)$, average relative humidity $(\mathrm{RH}, \%)$, wind speed $\left(\mathrm{U}, \mathrm{m} \mathrm{s}^{-1}\right)$ and solar radiation $\left(\mathrm{R}_{\mathrm{s}}, \mathrm{W} \mathrm{m}^{-2}\right)$ were measured by weather stations located near the study schemes, $10^{\circ} 54^{\prime} 54.1^{\prime \prime} \mathrm{N}$ and $0^{\circ} 49^{\prime} 35.3^{\prime \prime} \mathrm{W}$ in the BIS, and $10^{\circ} 50^{\prime} 44.6^{\prime \prime} \mathrm{N}$ and $0^{\circ} 54^{\prime} 43.9^{\prime \prime} \mathrm{W}$ in the VIS. Potential evapotranspiration was calculated based on the Penman-Monteith equation [40]:

$$
E T_{0}=\frac{1}{\lambda_{w}} \frac{\Delta\left(R_{n}-G\right)+\rho_{a} C_{p}\left(e_{s}-e_{a}\right)}{\Delta+\gamma_{a}\left(1+\frac{r_{c}}{r_{a}}\right)}
$$

where $E T_{0}$ is reference evapotranspiration $\left(\mathrm{mm} \mathrm{day}^{-1}\right), R_{n}$ is net radiation $\left(\mathrm{W} \mathrm{m}{ }^{-2}\right), G$ is soil heat flux $\left(\mathrm{W} \mathrm{m}^{-2}\right),\left(e_{s}-e_{a}\right)$ is the vapor pressure deficit of the air $(\mathrm{kPa}), \rho_{a}$ is mean air density at constant pressure $\left(\mathrm{kg} \mathrm{m}^{-3}\right), C_{p}$ is the specific heat of the air $\left(\mathrm{MJ} \mathrm{kg}^{-1}{ }^{\circ} \mathrm{C}^{-1}\right), \Delta$ is the slope of the saturation vapor pressure-temperature relationship $\left(\mathrm{kPa}^{\circ} \mathrm{C}^{-1}\right), \lambda_{w}$ is latent heat of vaporization $\left(\mathrm{MJ} \mathrm{kg}{ }^{-1}\right), \gamma_{a}$ is psychrometric constant $\left(\mathrm{kPa}^{\circ} \mathrm{C}^{-1}\right), r_{c}$ is crop resistance $\left(\mathrm{s} \mathrm{m}^{-1}\right)$, and $r_{a}$ is aerodynamic resistance $\left(\mathrm{s} \mathrm{m}^{-1}\right)$.

Next, the net irrigation requirement was calculated based on the actual evapotranspiration simulated in AquaCrop as follows [22,41]:

$$
N I R=\sum_{i=1}^{n}\left[\left(K_{c b}+K_{e}\right) E T_{0_{i}}-P_{e_{i}}-C R_{i}-W_{b_{i}}\right]
$$

where NIR is the net irrigation requirement $(\mathrm{mm}), n$ is the number of days in the crop cycle, $K_{c b}$ is the basal crop coefficient, $K_{e}$ is the evaporation coefficient, $P_{e}$ is effective rainfall $(\mathrm{mm}), C R$ is capillary rise $(\mathrm{mm})$, and $W_{b}$ is stored soil water (mm).

\subsubsection{Rainfall and Scenario Analyses}

Rainfall data during the years 1998-2014 were obtained for each scheme from the Tropical Rainfall Measuring Mission (TRMM) database. The total annual rainfall and total number and duration of dry spells were determined by the following conditions: (i) onset of rainfall is the beginning of a 10 day period between the second dekad of April and the first dekad of May during which the cumulative rainfall is $\geq 25 \mathrm{~mm}$, and a dry spell ensuing within 30 days from the start of the 10 day period is $\leq 8$ days [1,42]; (ii) cessation of rainfall is the last rainfall event between the third dekad of September and the second dekad of October [42]; (iii) dry spell is two or more consecutive non-rainy days [7], as even a period of two days without rainfall at critical growth stages is detrimental to crop production in savannah environments, particularly during periods of low rainfall; (iv) frequency of dry spells is the number of dry spells during the rainy season in the particular year under focus.

Additionally, the inter- and intra-seasonal variability of rainfall was expressed in the coefficient of variation based on the annual and monthly rainfall data, respectively:

$$
C V=\frac{\sigma}{\mu} * 100[\%]
$$

where $C V$ is the coefficient of variation, $\sigma$ is the standard deviation, and $\mu$ the mean of the rainfall data.

For the estimation of the supplemental irrigation requirement for maize, two climate scenarios (i.e., wet and dry rainfall regimes) were formulated based on rainfall amount and the frequency of dry spells. The first scenario (S1) was a wet year characterized by $\leq 20 \%$ probability of exceedance (i.e., the likelihood of the occurrence of rainfall $\geq 1057 \mathrm{~mm}$ ) and by less frequent dry spells [43]. The second scenario (S2) was a dry year characterized by $\geq 80 \%$ probability of rainfall occurrence exceeding $796 \mathrm{~mm}$ and by frequent dry spells [43] (Figure 4). 


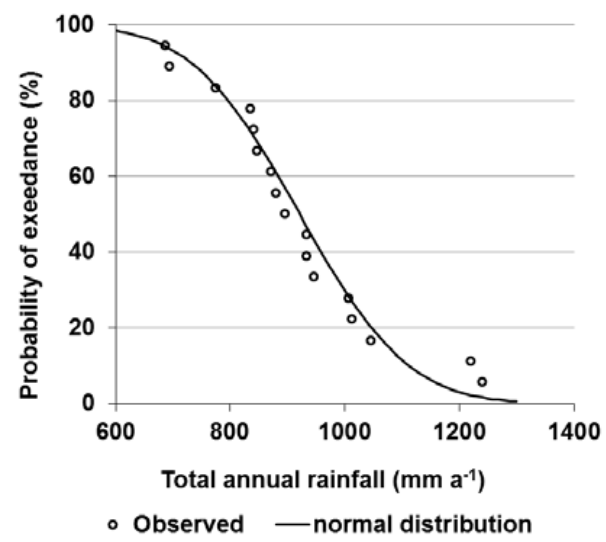

Figure 4. Probability plot of the total annual rainfall for the Vea and Bongo irrigation schemes for 1998-2014.

\subsubsection{Soil Characteristics}

Three soil profile pits were dug (at BF1 and BF4 in the BIS and at BNF2 in the VIS) to depths of $1.2-1.3 \mathrm{~m}$ in the Akrubu and Yaratanga soil series identified in the irrigation schemes. Soil samples were collected from the morphological soil horizons. The soil chemical properties, bulk density, soil moisture at saturation, field capacity, and permanent wilting point were determined in the laboratory [44] (Appendix A). Saturated hydraulic conductivity $\left(\mathrm{K}_{\text {sat }}\right)$ was determined in the laboratory by the falling head method [45] using undisturbed soil cores from the three soil pits. Comparison of the measured $\mathrm{K}_{\text {sat }}$ values with those determined from the pedo-transfer function based on soil texture and organic matter content $[39,46]$ revealed significantly lower values from the laboratory measurements. This is likely caused by incomplete saturation of the undisturbed soil samples (especially samples with high clay content) before the test, leakage along the metal cylinder during the test, and the impact of soil structure and macropores. Consequently, the $\mathrm{K}_{\mathrm{sat}}$ values determined from the pedo-transfer functions were used in the analysis.

\subsubsection{Crop Growth and Yield Parameters}

Sampling areas were demarcated within all selected fields for the collection of total aboveground biomass (AGB) [47]. Three rows were defined for bi-weekly AGB sampling, i.e., four times during the vegetative and reproduction stages. On each sampling day, three samples were collected per field from each defined row by cutting all plants along a $1 \mathrm{~m}$ rod. At harvest, two $8 \mathrm{~m}$ row sections in each of the selected fields were demarcated for AGB measurement. AGB was sampled and weighed as the yield components, i.e., maize grains and tomato fruits. The samples were weighed, oven-dried at $70-90{ }^{\circ} \mathrm{C}$ until a constant weight for at least $72 \mathrm{~h}$, and subsequently, the DM and the yield components were weighed. The planting dates differed from one farmer to another, hence the growth stages of the crops at the time of sampling were not the same. Due to the late start of the field data collection in 2014, the AGB of maize during the vegetative stage was not measured. The harvest index (HI) was estimated as the ratio of the dry yield component to total aboveground DM. The tomato yields in BF1, VF1 and BNF1 could not be assessed during the 2015-2016 season owing to the early onset of the rainy season in 2016, leading to waterlogging and failed tomato yields. Tomato yield measurements were therefore conducted in the neighboring fields characterized by similar soil conditions and farming practices. In the 2014 rainy season, only the BF1 maize field was monitored in the BIS, as the BF6 maize field was not cropped by the farmer. Crop data could not be collected in 2015 in both schemes owing to technical challenges.

Plant density (PD) was determined in all sampling fields. Row spacing was measured as the average distance between two adjacent rows at five random locations in the field [47]. Leaf area index (LAI) was measured bi-weekly using the SunScan probe (SS1-UM-2.0) at five random locations at each 
field. LAI was converted into canopy cover (CC) using Equation (4), which was developed for maize and soybean but is also applicable to other crops with a similar leaf shape [21,22]:

$$
C C=1.005[1-\exp (-0.6 L A I)]^{1.2}
$$

LAI measurements were interrupted in the 2014 rainy season and in the 2015-2016 dry season because of technical challenges. Maximum rooting depth (RD) was measured by manual excavations of at least three plants per crop at harvest time. A summary of all crop growth and yield parameters measured and details of their measurements each season is provided in Appendix B.

\subsubsection{Gross Irrigation Amount}

At the inlet of each of the selected fields, a Cipoletti weir, or a PVC pipe and a metallic staff gauge $(50 \mathrm{~cm})$ with metric graduation, was installed in the canal to measure the water inflow. A discharge equation for flow through the pipes during irrigation events was developed from in-situ measurements through a 'volumetric approach', using a bucket of a known volume $(17.5 \mathrm{~L})$ and a stopwatch. The time required to fill the bucket was recorded for seven different water depths read from the staff gauge. Discharges corresponding to the seven measured water depths were computed and, subsequently, discharge $\left(Q, \mathrm{~m}^{3} \mathrm{~s}^{-1}\right)$ was related to water depth $(\mathrm{h}, \mathrm{m})$ as follows:

$$
Q=0.073 h^{1.334}
$$

with $R^{2}=0.972$ and the standard error $=0.001$.

The actual water abstraction rate was measured using the volumetric approach in VF1, where pump irrigation was practiced. The discharge was summed up over the irrigation event for the estimation of the gross irrigation amount (GIA) per event.

\subsubsection{Groundwater and Capillary Rise}

Groundwater was monitored from 1 October, 2014 to 11 May, 2016 to analyze the impact of the groundwater table on water fluxes. Seven georeferenced wells were installed in the irrigable area of the VIS and five in the BIS (Figure 2) at characteristic locations, such as valley bottoms, lateral sites, sites near the dam, and in the middle of the schemes. PVC pipes perforated up to $1 \mathrm{~m}$ from the base were used. The depths of the wells ranged from 2.7 to $5.5 \mathrm{~m}$ in the VIS and from 2 to $4.9 \mathrm{~m}$ in the BIS. An electric contact meter (Seba KLL 077) was used to measure the depth to groundwater table weekly throughout the 2014-2016 observation period. However, measurements could not be carried out between 3 June, 2015 and 15 July, 2015 owing to technical challenges. Because of the late start of the groundwater monitoring in 2014, measurements from the 2015 rainy season were used for the simulation of rainfed maize for 2014.

Capillary rise was estimated in AquaCrop based on soil type and hydraulic characteristics [48] as follows:

$$
C R=\exp \left(\frac{\ln (z)-b}{a}\right)
$$

where $C R$ is the expected capillary rise in $\mathrm{mm} \mathrm{day}^{-1}, z$ is the depth to groundwater table in $\mathrm{m}$, and $a$ and $b$ are coefficients specific to the soil type and the hydraulic characteristics.

\subsection{Model Parameterization and Validation}

The 2014 rainy season dataset from VF1 was used to parameterize the AquaCrop model for maize and the 2014 maize dataset from BF1 was used to validate the model (i.e., inter-farm validation). The 2014 maize crop data from BNF1 were found to be unreliable owing to the effects of waterlogging, and thus were excluded from the analysis. For tomato, the 2014-2015 dry season data from BF1 were used for the parameterization, and inter-farm model validation was performed using 2014-2015 data 
from BF6. The inter-seasonal validation employed datasets from tomato BF1 collected in 2015-2016. Data from the other tomato fields (VF1 and BNF1) were either unavailable or incomplete owing to technical and environmental (i.e., crop disease attack) challenges in 2014-2015, and the early onset of rainfall destroying the crops in 2016.

The parameters modified in the model were climate, soil characteristics, and agronomic practice (Tables 1 and 2). All the default crop-specific parameters (i.e., yield response factor) for the study crops were used. The climate file in daily time-steps for the period 21 May, 2014 (i.e., beginning of the rainfed farming season in 2014) to 24 May, 2016 (i.e., end of the 2015-2016 dry season farming) was created using the AquaCrop $\mathrm{ET}_{0}$ file, maximum and minimum temperature file, and a rainfall file.

Table 1. Modified parameters and field data used for the parameterization and validation of the AquaCrop model for maize.

\begin{tabular}{|c|c|c|}
\hline Data Required & Model Parameterization & Inter-Farm Model Validation \\
\hline \multicolumn{3}{|l|}{ Site conditions } \\
\hline Cropping field & VF1 (2014) & BF1 (2014) \\
\hline Crop variety & 'Obatanpa' & 'Obatanpa' \\
\hline Growing cycle & 3 July, 2014-25 August, 2014 & 24 May, 2014-14 August, 2014 \\
\hline Planting method & Direct sowing & Direct sowing \\
\hline Soil fertility in relation to biomass & Poor & Poor \\
\hline Initial canopy cover & High canopy cover & High canopy cover \\
\hline Maximum canopy cover & Fairly covered & Fairly covered \\
\hline Maximum rooting depth & $0.30 \mathrm{~m}$ & $0.36 \mathrm{~m}$ \\
\hline Harvest index & 0.51 & 0.53 \\
\hline Crop development & In growing degree days & In growing degree days \\
\hline \multicolumn{3}{|l|}{ Field management } \\
\hline Soil surface cover & No mulch & No mulch \\
\hline Soil physical characteristics & $\begin{array}{l}\text { Field capacity, wilting point, soil moisture, texture, } \\
\text { and thickness of soil layer from soil pit } 3 \text { in BNF1 }\end{array}$ & $\begin{array}{l}\text { Field capacity, wilting point, soil moisture, texture, } \\
\text { and thickness of soil layer from soil pit } 1 \text { in BF1 }\end{array}$ \\
\hline Groundwater level & Weekly depth to groundwater table from VF1 well & Weekly depth to groundwater table from BR well \\
\hline Simulation period & Calendar of growing cycle & Calendar of growing cycle \\
\hline Field data file & Aboveground dry matter from VF1 & Aboveground dry matter from BF1 \\
\hline
\end{tabular}

Table 2. Modified parameters and field data for the parameterization and validation of the AquaCrop model for tomato.

\begin{tabular}{|c|c|c|c|}
\hline Data Required & Model Parameterization & Inter-Farm Model Validation & Inter-Seasonal Validation \\
\hline \multicolumn{4}{|l|}{ Site conditions } \\
\hline Cropping field & BF1 (2014-2015) & BF6 (2014-2015) & BF1 (2015-2016) \\
\hline Crop variety & 'Buffalo' & 'Buffalo' & 'Buffalo' \\
\hline Growing cycle & 22 October 22, 2014-11 February, 2015 & 11 November, 2014-6 March, 2015 & 23 November, 2015-18 March, 2016 \\
\hline Planting method & Transplanting & Transplanting & Transplanting \\
\hline Soil fertility in relation to biomass & Moderate & Moderate & Moderate \\
\hline Initial canopy cover & Very small cover & Very small cover & Very small cover \\
\hline Maximum canopy cover & Fairly covered & Fairly covered & Fairly covered \\
\hline Maximum rooting depth & $0.35 \mathrm{~m}$ & $0.37 \mathrm{~m}$ & $0.28 \mathrm{~m}$ \\
\hline Harvest index & 0.29 & 0.29 & 0.21 \\
\hline Crop development & In growing degree days & In growing degree days & In growing degree days \\
\hline \multicolumn{4}{|l|}{ Field management } \\
\hline Soil surface cover & No mulch & No mulch & No mulch \\
\hline Irrigation practice & $\begin{array}{c}\text { Irrigation amount per event in } \mathrm{mm} \\
\text { from BF1 }\end{array}$ & $\begin{array}{l}\text { Irrigation amount per event in } \mathrm{mm} \\
\text { from BF6 }\end{array}$ & $\begin{array}{c}\text { Irrigation amount per event in } \mathrm{mm} \\
\text { from BF6 }\end{array}$ \\
\hline Soil physical characteristics & $\begin{array}{l}\text { Field capacity, wilting point, soil } \\
\text { moisture, texture, and thickness of } \\
\text { soil layer from soil pit } 1 \text { in BF1 }\end{array}$ & $\begin{array}{c}\text { Field capacity, wilting point, soil } \\
\text { moisture, texture, and thickness of } \\
\text { soil layer field from soil pit } 2 \\
\text { near BF6 }\end{array}$ & $\begin{array}{l}\text { Field capacity, wilting point, soil } \\
\text { moisture, texture, and thickness of } \\
\text { soil layer from soil pit } 1 \text { in BF1 }\end{array}$ \\
\hline Groundwater level & $\begin{array}{l}\text { Weekly depth to groundwater table } \\
\text { from BR well }\end{array}$ & $\begin{array}{l}\text { Weekly depth to groundwater table } \\
\text { from BD well }\end{array}$ & $\begin{array}{l}\text { Weekly depth to groundwater table } \\
\text { from BR well }\end{array}$ \\
\hline Simulation period & Calendar of growing cycle & Calendar of growing cycle & Calendar of growing cycle \\
\hline Field data file & Aboveground dry matter from BF1 & Aboveground dry matter from BF6 & Aboveground dry matter from BF1 \\
\hline
\end{tabular}




\subsection{Supplemental Irrigation Requirement for Maize}

Irrigation scheduling was simulated for the maize fields (VF1 and BF1) by selecting the 'Net irrigation water requirement' option in AquaCrop, and 50\% allowable root zone depletion. The simulation was run to determine the supplemental irrigation requirement under the two aforementioned climate scenarios.

\subsection{Improved Irrigation Scheduling for Tomato}

Datasets from tomato fields (BF1 and BF6) in 2014-2015 were used to optimize the irrigation schedule. Irrigation files for each of the fields were created for the furrow irrigation method. The time criterion selected was 'Allowable depletion of $80 \%$ of readily available water' and the irrigation depth criterion used was 'Back to field capacity'. The irrigation water quality was specified as 'excellent' assuming a negligible salinity of irrigation water.

\section{Results}

\subsection{Rainfall Variability}

Rainfall data revealed a high inter-seasonal variability of rainfall (i.e., 17\%) and frequent dry spells lasting for 2-16 days (Figure 5). From 1998 to 2014, the frequency of dry spells in Vea and Bongo ranged between 18 and 28 occurrences. Furthermore, the analysis indicated increasing intra-seasonal rainfall variability in both schemes during the observation period, most likely due to climate change.

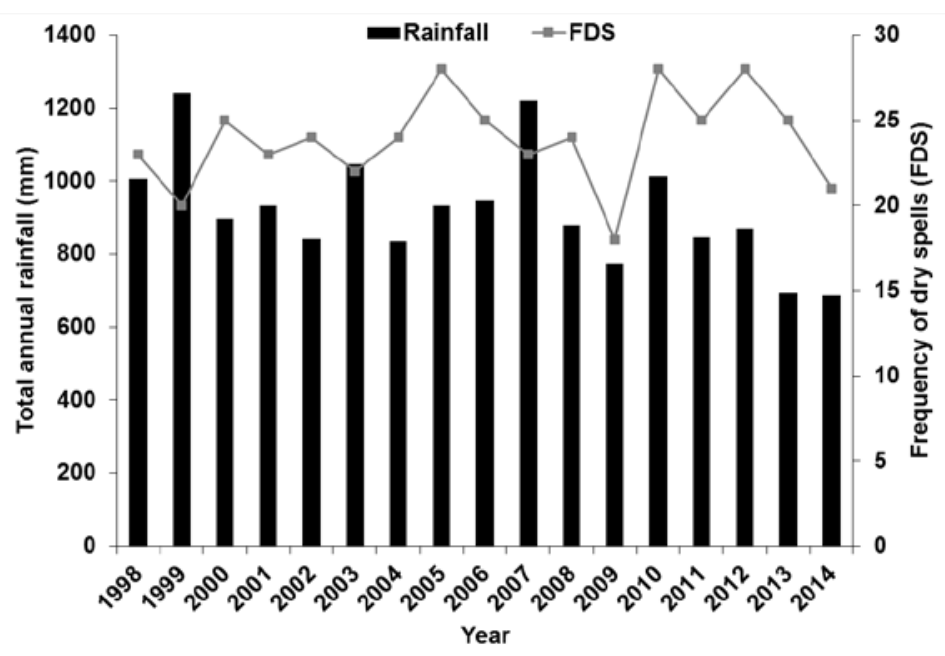

Figure 5. Total annual rainfall and frequency of dry spells (FDS) in the Vea and Bongo irrigation schemes during the years 1998-2014.

\subsection{Crop Growth Parameters}

The PD of maize ranged between 4.1 and 5.5 plants $\mathrm{m}^{-2}$ across the schemes (Table 3). The decline in the maize aboveground DM in VF1 and BNF1 in the VIS was attributed to the effects of late planting (i.e., 3 July, 2014) and waterlogging, respectively (Figure 6a). The PD of tomato was generally higher in the BIS (3.3-3.5 plants $\mathrm{m}^{-2}$ in 2014-2015, and 3.6-4.2 plants $\mathrm{m}^{-2}$ in 2015-2016) than in the VIS (2.6 plants $\mathrm{m}^{-2}$ in 2014-2015, and 3.3-3.5 plants $\mathrm{m}^{-2}$ in 2015-2016) (Table 3). The difference was partly due to the narrower inter-row spacing observed in the BIS $(0.28-0.35 \mathrm{~m})$ compared to that in the VIS $(0.25-0.54 \mathrm{~m})$. The remarkably low tomato DM in the Vea BNF1 field in 2014-2015 was due to the impact of plant root disease (Figure 6b). 
Table 3. Crop growth and yield components in the Bongo and Vea irrigation schemes during the 2014-2016 observation period.

\begin{tabular}{|c|c|c|c|c|c|c|}
\hline $\begin{array}{l}\text { Crop } \\
\text { Type }\end{array}$ & $\begin{array}{l}\text { Farm } \\
\text { Label }\end{array}$ & $\begin{array}{l}\text { Plant Density } \\
\text { (plants } \mathrm{m}^{-2} \text { ) }\end{array}$ & $\begin{array}{l}\text { Maximum Rooting } \\
\text { Depth (m) }\end{array}$ & $\begin{array}{l}\text { Fresh Yield } \\
\left(\mathrm{Mg} \mathrm{ha}^{-1}\right)\end{array}$ & $\begin{array}{l}\text { Dry Yield } \\
\left(\mathrm{Mg} \mathrm{ha}^{-1}\right)\end{array}$ & $\begin{array}{c}\text { Harvest } \\
\text { Index }\end{array}$ \\
\hline \multicolumn{3}{|c|}{ Bongo irrigation scheme } & \multicolumn{4}{|c|}{2014 rainy season } \\
\hline \multirow[t]{2}{*}{ Maize } & BF1 & 4.4 & 0.36 & n.d. & 2.9 & 0.53 \\
\hline & & & \multicolumn{4}{|c|}{ 2014-2015 dry season } \\
\hline Tomato & BF1 & 3.5 & 0.35 & 49.2 & 2.3 & 0.29 \\
\hline \multirow[t]{2}{*}{ Tomato } & BF6 & 3.3 & 0.37 & 34.3 & 2.5 & n.d. \\
\hline & & & \multicolumn{4}{|c|}{ 2015-2016 dry season } \\
\hline Tomato & BF1 & 3.6 & 0.28 & 42.8 & 1.4 & 0.22 \\
\hline Tomato & BF6 & 4.2 & n.d. & 39.6 & 1.6 & 0.21 \\
\hline \multicolumn{3}{|c|}{ Vea irrigation scheme } & \multicolumn{4}{|c|}{2014 rainy season } \\
\hline Maize & VF1 & 5.5 & 0.30 & n.d. & 2.6 & 0.51 \\
\hline \multirow[t]{2}{*}{ Maize } & BNF1 & 4.1 & 0.35 & n.d. & 1.2 & 0.41 \\
\hline & & & \multicolumn{4}{|c|}{ 2015-2016 dry season } \\
\hline Tomato & VF1 & 3.3 & 0.24 & 35.3 & 1.6 & 0.29 \\
\hline Tomato & BNF1 & 3.5 & 0.29 & 51.3 & 2.2 & 0.30 \\
\hline
\end{tabular}

n.d. = not determined /applicable
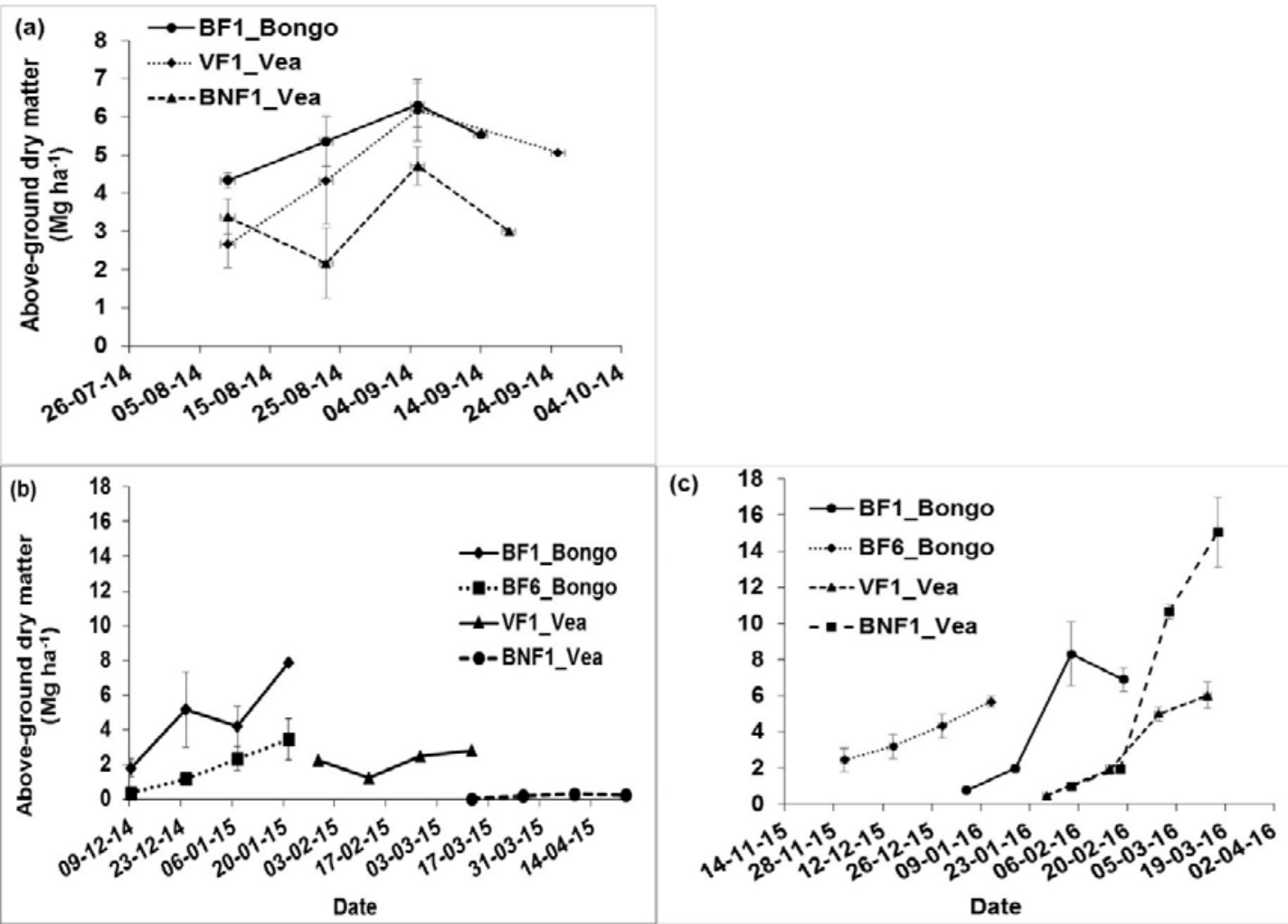

Figure 6. Aboveground dry matter of (a) maize in 2014; (b) tomato in 2014-2015 and (c) tomato in 2015-2016 in the Bongo and Vea irrigation schemes.

The higher tomato DM observed in the 2015-2016 dry season compared to the previous dry season could be due to excessive field-level water application in that season, when an increased water availability was recorded (Figure $6 b, c$ ). The downward trend of the LAI of tomato observed in the BIS 
in 2014-2015 might be due to an insufficient water supply in the later part of the dry season. In contrast, the upward trend of the LAI in the VIS reflects an adequate water supply (Figure 7). The maximum $\mathrm{RD}$ of tomato and maize ranged between 0.28 and $0.37 \mathrm{~m}$ (Table 1 ), a result of the shallow soil depth, not exceeding $0.4 \mathrm{~m}$ in the UER.

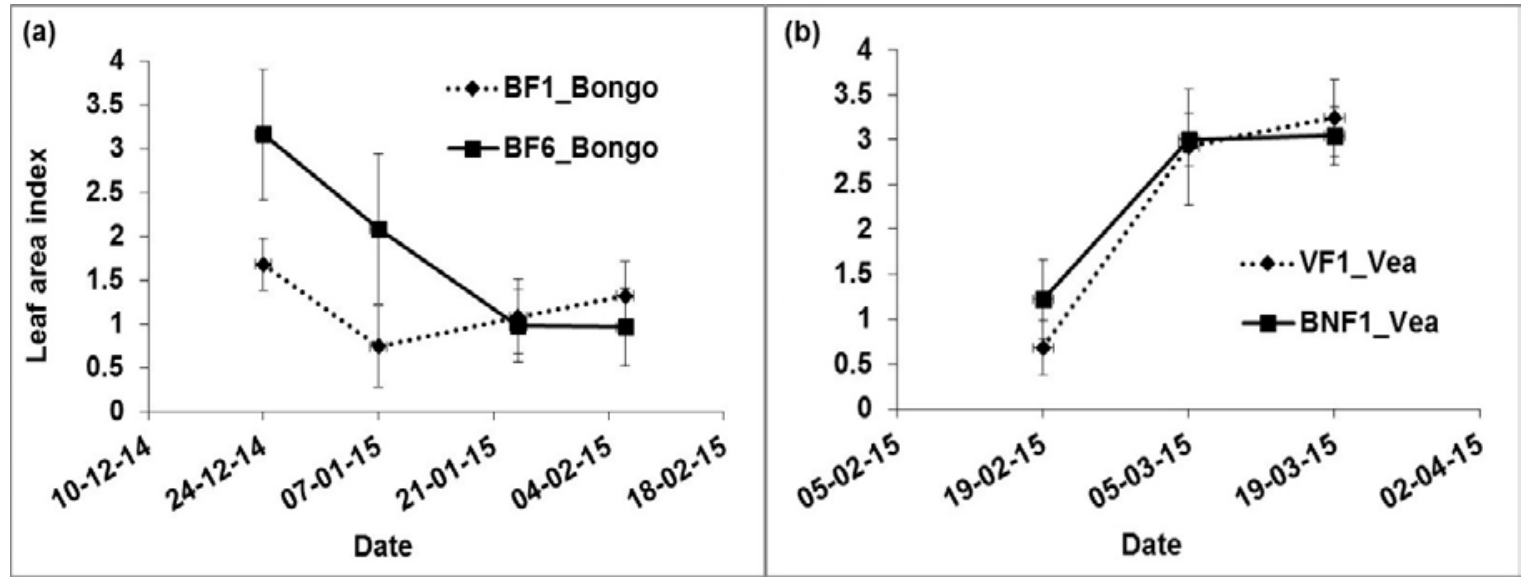

Figure 7. Leaf area index of tomato during the 2014-2015 dry season in the (a) Bongo and (b) Vea irrigation schemes.

\subsection{Crop Yield Components}

In 2014, the maize yield ranged between 1.2 and $2.9 \mathrm{Mg} \mathrm{ha}^{-1}$, and the $\mathrm{HI}$ ranged from 0.41 to 0.53 across the irrigation schemes (Table 3). A relatively low yield was observed in the BNF1 maize field, in the VIS, possibly due to the combined effect of late planting and waterlogging that occurred in this farm. A relatively high maize yield was recorded in the BIS. The overall range for the annual fresh yields of tomato was $34.3-51.3 \mathrm{Mg} \mathrm{ha}^{-1}$ across the irrigation schemes and monitoring periods, and the tomato $\mathrm{HI}$ ranged between 0.21 and 0.3 .

\subsection{Groundwater Level and Capillary Rise}

The average depth to groundwater table varied between 0.7 and $2.8 \mathrm{~m}$ in the VIS and between 0.6 and $1.3 \mathrm{~m}$ in the BIS during 2014-2016 (Figure 8). In the BIS, the soil waterlogging (detected in the BM well) occurred in August and the deepest level (3 m measured in the BD well) was observed in May. The BNF2 well in the VIS recorded the shallowest groundwater level $(0.1 \mathrm{~m})$ in August, while the VF1 well measured the deepest groundwater level $(3.4 \mathrm{~m})$ in May. The rise in the groundwater table in August most likely resulted from rainfall recharge.

Furthermore, the groundwater level was influenced by nearby streams, reservoirs, and fish ponds. For example, the BU well in the BIS and the VU, BNM and BoN wells in the VIS exhibited stable and relatively shallow groundwater levels due to their proximity to the Bongo reservoir, Vea fish ponds, and streams, even when deep groundwater levels were recorded at other wells (Figure 8). Irrigation events also impacted on the water table. For instance, the groundwater level in the BF1 well in the tomato field increased steadily from the beginning of the dry season and declined from 4 March, 2015, when 2014-2015 dry season irrigation was over. However, the VF1 and BNF2 wells in the VIS in the tomato and leafy vegetable fields, respectively, exhibited rather variable groundwater levels even during the irrigation period and a downward trend after the end of the irrigation period.

The simulated capillary rise into the root-zone of maize was $43-147 \mathrm{~mm}$ in 2014 , while in the tomato fields it was 18-157 $\mathrm{mm}$ in 2014-2015, and 27-263 $\mathrm{mm}$ in the 2015-2016 across the irrigation schemes (Figure 9). 


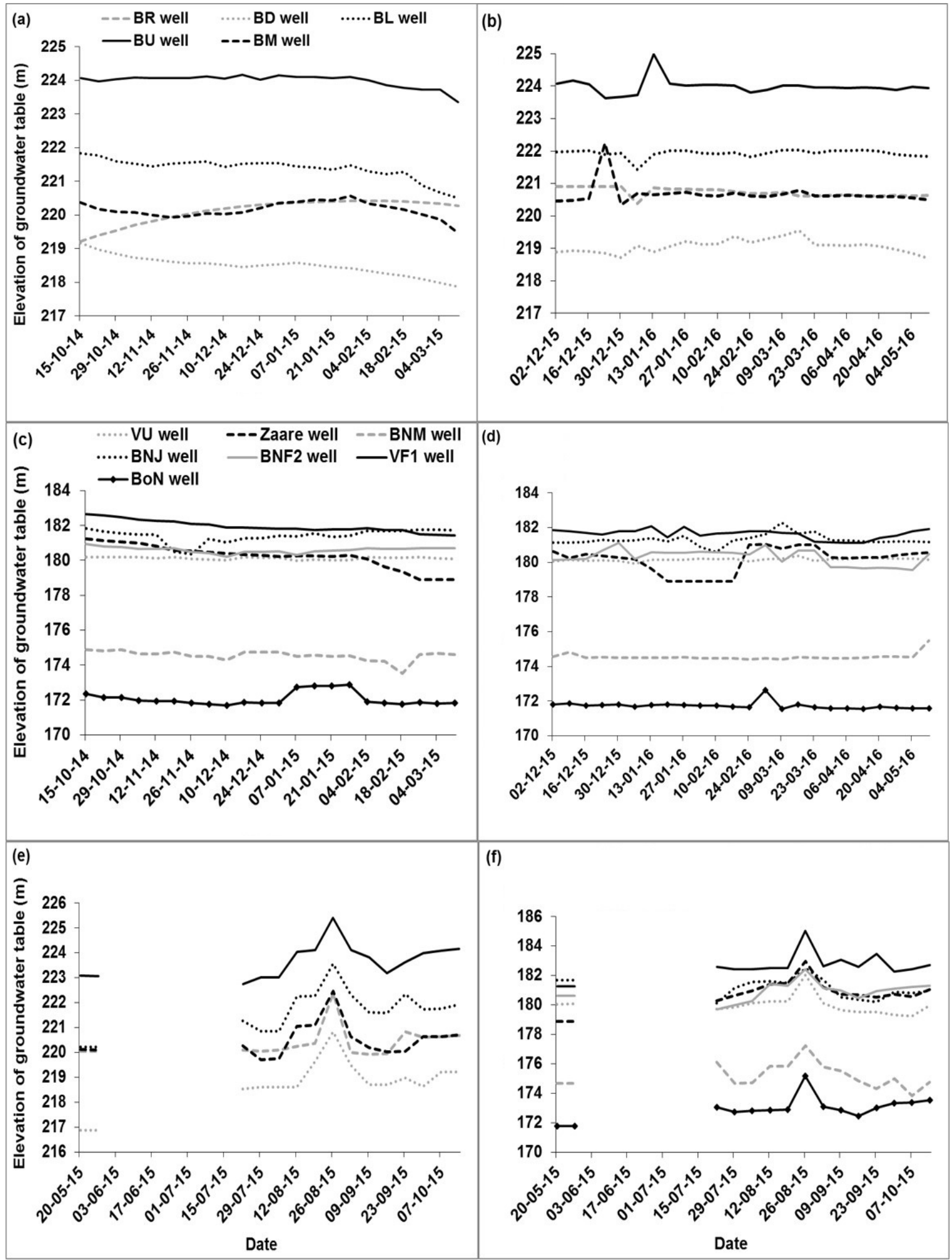

Figure 8. Elevation of the groundwater table during (a) 2014-2015 dry season in Bongo (b) 2015-2016 dry season in Bongo (c) 2014-2015 dry season in Vea (d) 2015-2016 dry season in Vea (e) 2015 rainy season in Bongo and (f) 2015 rainy season in Vea. 


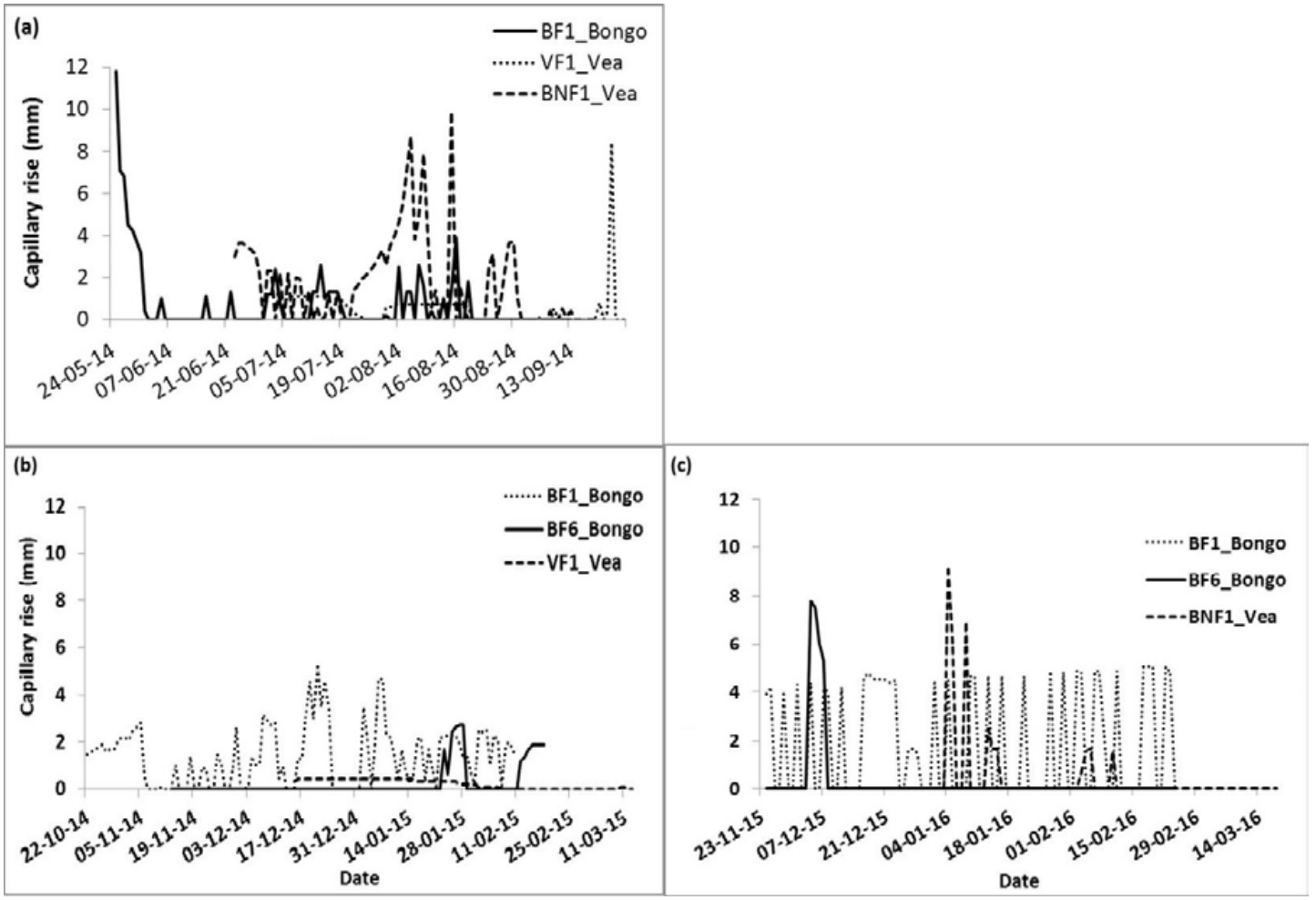

Figure 9. Daily groundwater contribution to the root-zone soil moisture of (a) maize in 2014; (b) tomato in 2014-2015 and (c) 2015-2016 computed by AquaCrop.

\subsection{Traditional Irrigation Scheduling}

The observed GIA for dry season tomato was lower in 2014-2015 than in 2015-2016 in both schemes (Table 4). Across both irrigation schemes and both dry seasons, the overall range of GIA was 21-67 mm per irrigation event and 584-2559 $\mathrm{mm}$ per season. The number of irrigation events for tomato ranged between 20 and 29 in both dry seasons. Particularly in the BIS, the irrigation interval in the tomato fields was generally shorter in 2015-2016 than in the previous dry season, owing to the increased availability of water in the Bongo reservoir.

Table 4. Observed field-level irrigation practices and water productivity for tomato in the Bongo and Vea irrigation schemes during the dry seasons.

\begin{tabular}{|c|c|c|c|c|}
\hline Field Label & $\begin{array}{l}\text { Gross Irrigation } \\
\text { Amount Per } \\
\text { Season }(\mathrm{mm})\end{array}$ & $\begin{array}{l}\text { Gross Irrigation } \\
\text { Amount Per Event } \\
(\mathrm{mm})\end{array}$ & $\begin{array}{l}\text { Average Irrigation } \\
\text { Interval (day) }\end{array}$ & $\begin{array}{l}\text { Water Productivity } \\
\left(\mathrm{kg} \mathrm{m}^{-3}\right)\end{array}$ \\
\hline Bongo irrigation scheme & & 2014-2015 & & \\
\hline BF1 & 586 & $19-50$ & 4 & 8.4 \\
\hline BF6 & 1247 & $17-137$ & 5 & 2.7 \\
\hline \multicolumn{5}{|c|}{$2015-2016$} \\
\hline BF1 & 1719 & $20-93$ & 3 & 2.5 \\
\hline BF6 & 2559 & $14-133$ & 2 & 1.5 \\
\hline Vea irrigation scheme & & 2014-2015 & & \\
\hline VF1 & 615 & $13-35$ & 5 & n.d. \\
\hline BNF1 & 584 & $21-42$ & 5 & n.d. \\
\hline \multicolumn{5}{|c|}{$2015-2016$} \\
\hline BNF1 & 1137 & $33-79$ & 4 & 4.5 \\
\hline
\end{tabular}

n.d. $=$ not determined . 


\subsection{Model Performance}

The results of model evaluation for tomato DM indicated good agreement $(\mathrm{EF}=0.65-0.83$, and $\mathrm{d}=0.87-0.96)$ and acceptable error margins (NRMSE $=17.7-42 \%$ ) (Figure 10c-e).
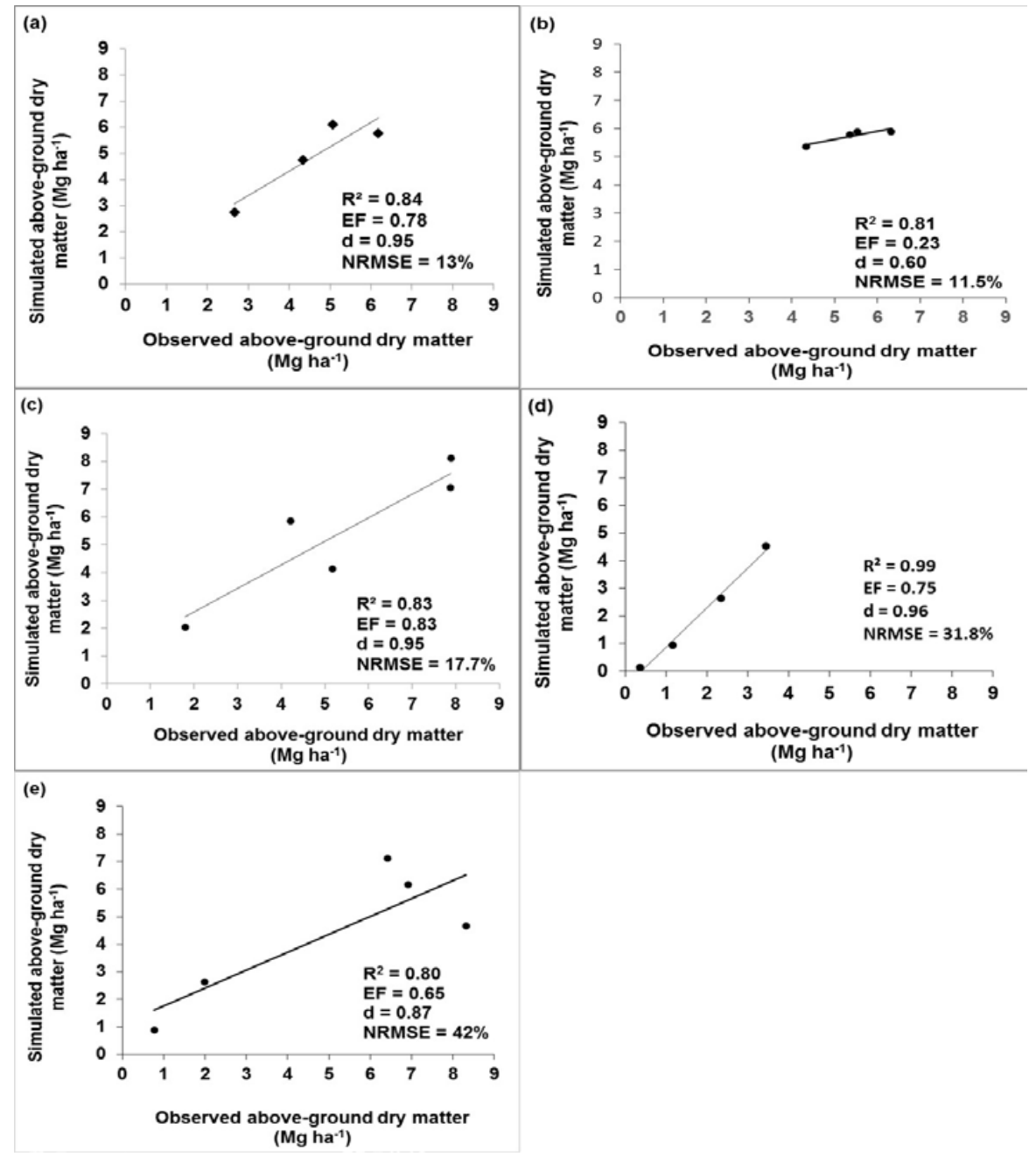

Figure 10. Evaluation of simulated and observed aboveground dry matter of (a) maize in VF1 in 2014; (b) maize in BF1 in 2014; (c) tomato in BF1 in 2014-2015; (d) tomato in BF6 in 2014-2015; and (e) tomato in BF1 in 2015-2016, in the Vea and Bongo irrigation schemes.

The model evaluation for maize $\mathrm{DM}$ also suggested a good agreement $(\mathrm{EF}=0.23-0.78$, and $\mathrm{d}=0.60-0.95)$ and an acceptable error margin (NRMSE $=11.5-13 \%$ ). However, the low EF (0.23) for maize in the BF1 field (Figure 10b) could be due to the missing biomass data for the vegetative stage due to the late start of data collection.

\subsection{Improved Irrigation Schedule for Tomato}

The optimized irrigation schedule for the dry season tomato cropping indicated the need for longer irrigation intervals (6-13 days) in the early crop growth stage and during ripening. In contrast, irrigation intervals should be shorter (2-8 days) in the flowering and yield formation stages (Figure 11). The simulated NIR for tomato ranged from 21 to $29 \mathrm{~mm}$ per irrigation event and from 311 to $495 \mathrm{~mm}$ per season. The GIA for tomato was estimated as $38-52 \mathrm{~mm}$ per irrigation event and $566-900 \mathrm{~mm}$ per season, assuming a $55 \%$ application efficiency. 


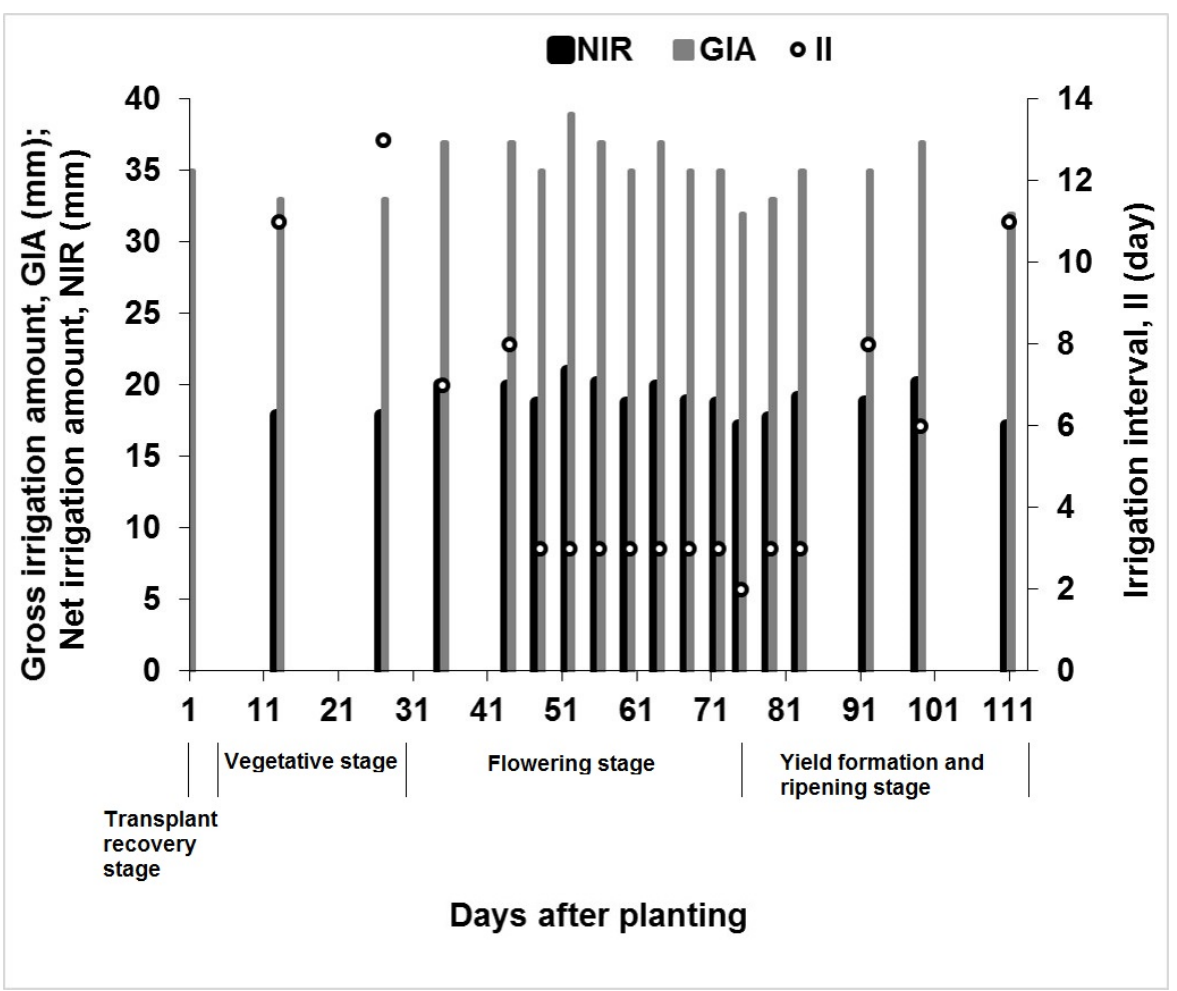

Figure 11. Improved irrigation schedule for tomato cultivation, based on the example of BF1 in the Bongo irrigation scheme. Gross irrigation amount was estimated using a field application efficiency of $55 \%$ [19].

The improved irrigation schedule would result in $4-14 \%$ yield increment while saving $130-1325 \mathrm{~mm}(22-52 \%$ of GIA) of water, which is otherwise lost through percolation beyond the root zone under the traditional irrigation practice in either scheme (Table 5).

Table 5. Potential water saving and yield increase under the improved irrigation schedule as simulated in AquaCrop.

\begin{tabular}{ccccc}
\hline Field Label & $\begin{array}{c}\text { Potential Water } \\
\text { Saving (mm) }\end{array}$ & $\begin{array}{c}\text { Tomato Yield under } \\
\text { Traditional Irrigation } \\
\mathbf{( M g ~ h a ~}^{-1} \mathbf{)}\end{array}$ & $\begin{array}{c}\text { Tomato Yield under } \\
\text { Improved Irrigation } \\
\mathbf{( M g ~ h a}^{-1} \mathbf{)}\end{array}$ & $\begin{array}{c}\text { Potential Yield } \\
\text { Increase (\%) }\end{array}$ \\
\hline BF1 (2014-2015) & 130 & 2.30 & 2.40 & 4 \\
\hline BF6 (2014-2015) & 775 & 2.01 & 2.30 & 14 \\
\hline BF1 (2015-2016) & 1,325 & 1.58 & 1.79 & 14 \\
\hline
\end{tabular}

\subsection{Supplemental Irrigation Requirement for Maize}

S1 was observed in 1999 when $1240 \mathrm{~mm}$ of rainfall and 20 dry spells were recorded in the rainy season, and S2 was observed in 2012 with $871 \mathrm{~mm}$ of rainfall and 28 dry spells, the highest frequency of dry spells during the 17 year observation period (Figure 5). Notably, although 2014 recorded the lowest rainfall $(687 \mathrm{~mm})$, it was not considered the driest year due to the lower frequency of dry spells (21) compared with 2012. The supplemental irrigation requirement for rainfed maize in the favorable climate scenario S1 was predicted in the range of $88-105 \mathrm{~mm}$ (i.e., $25-29 \%$ of NIR of maize). The values predicted for S2, the scenario of low rainfall and frequent dry spells, ranged between 107 and $126 \mathrm{~mm}$ (i.e., $30-35 \%$ of NIR of maize) (Figure 12). The simulated increase in maize yield under supplemental irrigation ranged between $5 \%$ and $14 \%$. 

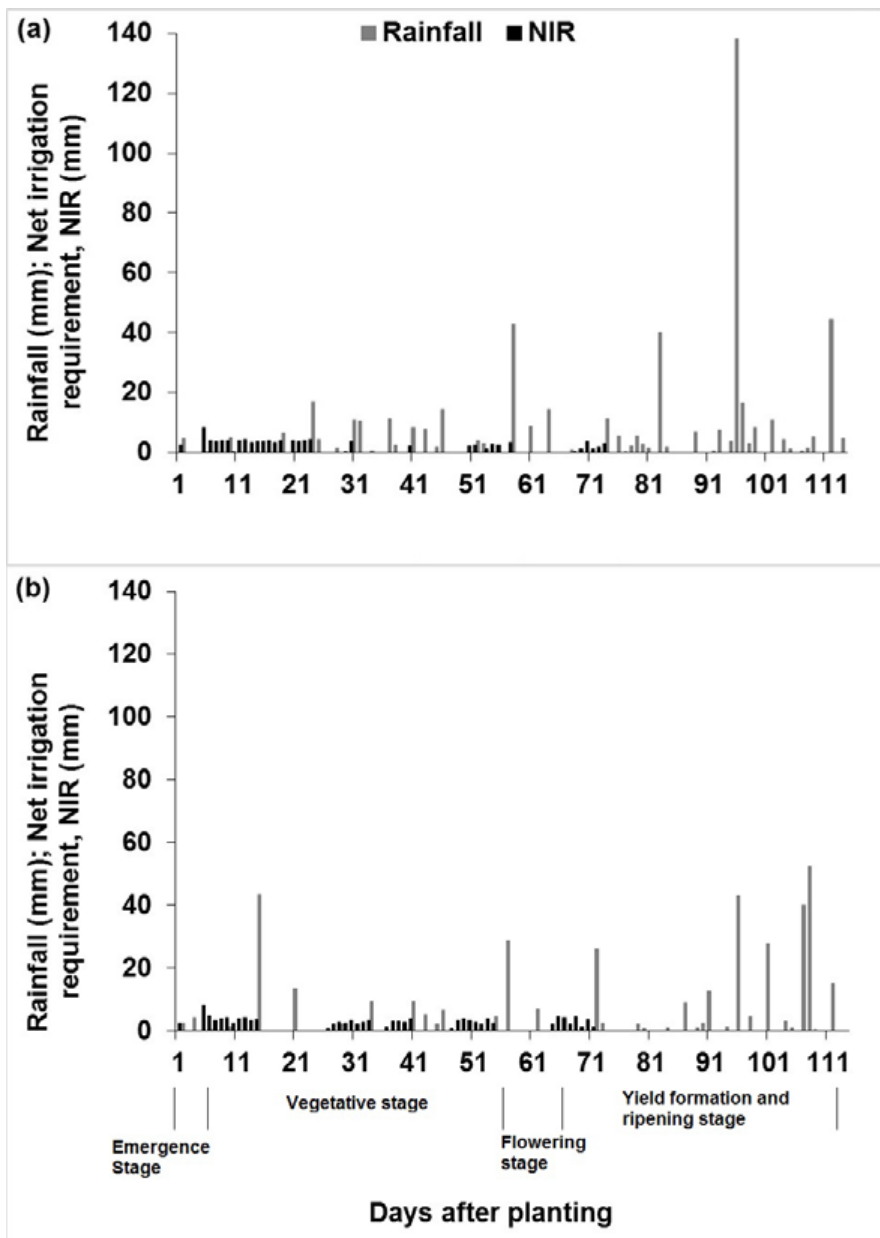

Figure 12. Daily rainfall and net irrigation requirement for supplemental irrigation of maize in the (a) 1999 wet year and (b) 2012 dry year, as simulated in AquaCrop based on the example of maize BF1 in the Bongo irrigation scheme.

\section{Discussion}

\subsection{Crop Yields}

The yields of fresh tomato fruits were similar across schemes but varied remarkably between fields owing to differences in field-level agronomic and irrigation practices and constraints. For instance, the tomato root disease in the VIS field impacted negatively on yield, as the application of insecticides protected only the aboveground biomass. Over-irrigated tomato in 2015-2016 showed high fresh yields and the higher water content of these fruits (i.e., 95\% vs. 93\% in water-scarce 2014-2015). The values of tomato fresh yield corresponded to the upper ranges measured by [35], reporting $20-36.8 \mathrm{Mg} \mathrm{ha}^{-1}$ of fresh tomato yields in the UER, and were greater than the $18 \mathrm{Mg} \mathrm{ha}^{-1}$ reported by [49] for rainfed tomato production in the Ashanti and Brong Ahafo regions of Ghana, reflecting the positive impact of irrigation. However, the lower HI of tomato observed in our study (0.21-0.3), compared to values (0.5-0.65) reported by [22] for rainfed tomato in drylands, could be partly due to over-irrigation. The excessive water use was reflected in the low field application efficiencies (30-59\%) characteristic of almost all the examined fields [19].

Late planting and waterlogging, due to the lack of drainage facilities, reduced maize grain yield to only $1.2 \mathrm{Mg} \mathrm{ha}^{-1}$ in the affected field in the VIS. This observation confirms late planting as one of the causes of sub-optimal yield levels of rainfed maize as rainfall typically declines towards the end of the rainy season. Sallah et al. [50] reported a 30\% loss in maize yields due to late planting in northern 
Ghana. The observed range of maize grain yields in our study $\left(1.2-2.9 \mathrm{Mg} \mathrm{ha}^{-1}\right)$ was similar to that reported for the fertilized 'Obatanpa' maize variety in Ghana (1.3 to $2.7 \mathrm{Mg} \mathrm{ha}^{-1}$; [38]). The values of [8] for SSA (1.3-1.4 $\mathrm{Mg} \mathrm{ha}^{-1}$ ) were within the lower range of our results. However, Sugri et al. [51] reported the yield potential of the 'Obatanpa' maize variety to be $5.5 \mathrm{Mg} \mathrm{ha}^{-1}$ in Ghana. Variations in practices of soil nutrient management and often insufficient applications of fertilizer in the examined fields could also have contributed to the variability in yields. Folberth et al. [9] emphasized that even modest additions of $\mathrm{N}$ and $\mathrm{P}$ fertilizer might double maize production in most of SSA.

\subsection{Irrigation Practice}

The examination of field-level irrigation practices during the dry season revealed inappropriate, and in turn, ineffective water application for crop production resulting in over-irrigation in both schemes, mainly due to the lack of consideration of the crop growth stages and water storage characteristics of the soil. Over-irrigation was signified by the high GIA in the water-abundant 2015-2016 season, when farmers in both schemes used more water by shortening irrigation intervals (Table 4), leading to lower water productivity than in the previous, water-scarce season. Because of the lack of appropriate irrigation scheduling and the absence of flow measuring devices in the canals, farmers applied as much water as possible to the tomato crop, and further increased the water application rate with increasing water availability in the reservoir. Faulkner et al. [33] also observed the tendency for excessive water use in response to increasing water availability and attributed this phenomenon to the lack of knowledge of efficient and effective water application at field level. Moreover, the GIAs of tomato in our study were 100-400\% larger than the range of values, 274 and $852 \mathrm{~mm}$, previously reported for the UER [34,35], confirming the need for water saving.

\subsection{Improved Irrigation Scheduling}

The need to adjust irrigation schedules to local hydro-geological conditions is suggested by the modelling analysis, for example, a significant contribution of capillary rise from the groundwater was shown to satisfy the NIR of crops. The groundwater contribution to the NIR of the study crops was highly variable, reflecting the spatial variability in hydro-geological characteristics of the cropping fields. The need to account for this variability complicates the development and application of improved farmer irrigation scheduling in the UER. According to [52], there could be varying contributions of shallow groundwater $(\leq 3 \mathrm{~m})$ to the root-zone soil moisture in fine-textured soils such as those mostly found in the Bongo and Vea irrigation schemes.

The observed increases in tomato yield (i.e., 4-14\%) under the improved irrigation schedule most likely resulted from the reduction of the negative effect of over-irrigation on crop yield, as the over-irrigated cropping fields showed the highest potential (14\%) to increase yields under the improved irrigation schedule. The simulated magnitude of water saving in the reservoir-based irrigation schemes, which was $22-52 \%$ of the GIA under the current irrigation practices, indicates that improving irrigation schedules offers considerable potential for water saving in the dry season in the UER irrigation systems. Overall, however, the improvement of field-level irrigation scheduling alone might not be sufficient for optimizing water productivity and availability in the schemes [16]. To achieve full benefits, equipping irrigation infrastructure with discharge-measuring and dosage structures, and reparation of the decaying water conveyance and distribution sub-systems in the UER would be necessary [18-20]. These interventions to upgrade infrastructure would need to be accompanied by the training of irrigators to handle these facilities, and by further development of water management institutions towards reliably implementing advanced irrigation schedules in order to utilize the full potential of improvements.

\subsection{Feasibility of Supplemental Irrigation}

The observed temporal variability in rainfall across the irrigation schemes highlights the urgent need for water management strategies to ensure a reduction of the associated risks in rainfed crop 
production. The intra-seasonal variability of rainfall revealed by the frequency of dry spells was found to be more influential on water demand for crop growth than the total rainfall over the growing season. In the VIS, for example, the supplemental irrigation requirement for maize simulated with the 2014 rainfall was $29 \mathrm{~mm}$, whereas in the wetter year 2012, this value was $107 \mathrm{~mm}$ due to the higher frequency of dry spells (28). Similarly, although 1999 was recognized as the wet year for S1 according to the aforementioned criteria, the simulated NIR for supplemental irrigation of maize was $88 \mathrm{~mm}$ due to the higher intra-seasonal variability $(69 \%)$ in that year than in $2014(64 \%)$.

The supplemental irrigation requirement for maize estimated by AquaCrop (29-126 mm) was within the range of values, 20-240 mm, determined by [5] in semi-arid Mwala in Kenya. Furthermore, the temporal rainfall variability was consistent with the findings of [37], who observed high rainfall variability of $>25 \%$ during the years 1923-1995 in the Sahelian region. Likewise, [7] estimated dry spells lasting for 2-13 days in the Savanna agro-ecological zone of Ghana.

Overall, considering only the crop irrigation sector, the quantity of water saved through improved irrigation scheduling of dry season tomato is largely sufficient to accommodate supplemental irrigation of maize in the rainy season, and thus adapt to rainfall variability and recurrent dry spells. Even for the dry climate scenario of low rainfall coupled with frequent dry spells, about $126 \mathrm{~mm}$ of water at field level would be required for the supplemental irrigation of maize during the rainy season. Furthermore, the simulated increase in maize yield upon the introduction of supplemental irrigation offers an incentive for managers of the Bongo and Vea schemes to explore this strategy. Notably, due to the reservoir losses through evaporation and seepage, some of the water saved in the dry season might not be available for supplemental irrigation in the rainy season. Hence, an effective year-round irrigation schedule is required so that supplemental irrigation in the rainy season does not compromise water availability for dry season crop production.

\section{Conclusions}

High temporal variability in rainfall and frequent dry spells lasting for 2-16 days are common in the UER, requiring adaptive measures to enhance rainfed crop production. The supplemental irrigation requirement for maize under the dry climate scenario of low rainfall and frequent dry spells was estimated between 107 and $126 \mathrm{~mm}$, whereas for periods of high rainfall and rare dry spells, between 88 and $105 \mathrm{~mm}$ would be required. These demands can be satisfied via improved irrigation scheduling for dry season tomato that can potentially save $130-1325 \mathrm{~mm}$ of water, which would otherwise be lost through percolation and evaporation. Tomato and maize yield increments in the range of $4-14 \%$ and $5-14 \%$, respectively, are predicted under the improved irrigation schedule and supplemental irrigation. The AquaCrop model, parameterized using field data collected in the small- and medium-scale reservoir-based irrigation schemes in the Upper East region of Ghana, can be further utilized to improve the irrigation schedule of other cropping systems in the UER. Given the sub-optimal nutrient management practices observed across the study sites, further research should investigate the potential of both soil fertility and water management practices combined for improving crop yields and year-round food security in sub-Saharan Africa.

Author Contributions: E.S.-A., B.T., B.D. and A.K. conceived and designed the field surveys; E.S.-A. performed the surveys; E.S.-A. and B.T. analyzed the data; E.S.-A., B.T., B.D. and A.K. wrote the paper.

Acknowledgments: This study was supported by the German Federal Ministry of Education and Research (BMBF) under the program WASCAL (West African Science Service Center on Climate Change and Adapted Land Use, project No. 00100218). The additional support by the German Academic Exchange Service (DAAD) and Korea University Grant (No. K1608421) is gratefully acknowledged. This paper was presented at the 23rd ICID Congress on Irrigation and Drainage in Mexico City, Mexico.

Conflicts of Interest: The authors declare no conflict of interest. The founding sponsors had no role in the design of the study; in the collection, analyses, or interpretation of data; in the writing of the manuscript, and in the decision to publish the results. 


\section{Appendix A}

Table A1. Chemical properties of soils in the Bongo and Vea irrigation schemes.

\begin{tabular}{|c|c|c|c|c|c|c|c|c|c|c|c|c|c|c|}
\hline \multirow{2}{*}{$\begin{array}{l}\text { Morphological } \\
\text { Horizon (cm) }\end{array}$} & \multicolumn{12}{|c|}{ Exchangeable Cations $\left(\mathrm{cmol} \mathrm{kg}^{-1}\right)$} & \multicolumn{2}{|c|}{ Available-Brays } \\
\hline & $\begin{array}{c}\mathrm{pH} \\
\left(1: 1 \mathrm{H}_{2} \mathrm{O}\right)\end{array}$ & OC (\%) & $\begin{array}{c}\text { Total N } \\
(\%)\end{array}$ & $\begin{array}{l}\text { OM } \\
(\%)\end{array}$ & $\mathrm{Ca}^{2+}$ & $\mathrm{Mg}^{2+}$ & $\mathbf{K}^{+}$ & $\mathrm{Na}^{+}$ & $\begin{array}{c}\text { TEB } \\
\left(\mathrm{cmol} \mathrm{kg}^{-1}\right)\end{array}$ & $\begin{array}{c}\text { EA } \\
\left(\mathrm{cmol} \mathrm{kg}^{-1}\right)\end{array}$ & $\begin{array}{c}\text { CEC } \\
\left(\mathrm{cmol} \mathrm{kg}^{-1}\right)\end{array}$ & BS (\%) & ppmP & ppmK \\
\hline \multicolumn{15}{|l|}{ Pit 1} \\
\hline $0-12$ & 6.5 & 1.44 & 0.16 & 2.48 & 3.20 & 0.80 & 0.08 & 0.04 & 4.12 & 0.15 & 4.27 & 96.49 & 26.95 & 31.19 \\
\hline $12-30$ & 7.0 & 0.41 & 0.06 & 0.71 & 4.01 & 1.07 & 0.04 & 0.03 & 5.15 & 0.15 & 5.30 & 97.17 & 5.50 & 13.25 \\
\hline $30-56$ & 7.2 & 0.34 & 0.04 & 0.59 & 2.94 & 1.07 & 0.03 & 0.03 & 4.07 & 0.05 & 4.12 & 98.79 & 2.55 & 10.56 \\
\hline $56-75$ & 7.1 & 0.21 & 0.04 & 0.36 & 1.34 & 1.07 & 0.02 & 0.02 & 2.45 & 0.50 & 2.95 & 83.05 & 1.99 & 8.23 \\
\hline $75-100$ & 7.9 & 0.14 & 0.03 & 0.24 & 2.40 & 1.07 & 0.04 & 0.30 & 3.81 & 0.03 & 3.84 & 99.22 & 3.11 & 11.03 \\
\hline $100-125$ & 7.9 & 0.07 & 0.02 & 0.12 & 2.14 & 1.60 & 0.03 & 0.03 & 3.80 & 0.03 & 3.83 & 99.22 & 0.88 & 12.98 \\
\hline \multicolumn{15}{|l|}{ Pit 2} \\
\hline $0-20$ & 7.8 & 1.75 & 0.16 & 3.02 & 15.49 & 7.34 & 0.09 & 0.06 & 22.98 & 0.05 & 23.03 & 99.78 & 34.12 & 35.14 \\
\hline $20-44$ & 8.4 & 0.51 & 0.07 & 0.88 & 9.08 & 5.07 & 0.10 & 0.06 & 14.31 & 0.03 & 14.34 & 99.79 & 2.79 & 37.12 \\
\hline $44-80$ & 8.7 & 0.34 & 0.04 & 0.59 & 7.08 & 4.01 & 0.10 & 0.06 & 11.25 & 0.03 & 11.28 & 99.73 & 0.24 & 38.62 \\
\hline $80-120$ & 8.8 & 0.31 & 0.04 & 0.53 & 8.28 & 11.21 & 0.10 & 0.06 & 19.65 & 0.03 & 19.68 & 99.85 & 1.59 & 34.21 \\
\hline \multicolumn{15}{|l|}{ Pit 3} \\
\hline $0-20$ & 7.3 & 0.72 & 0.09 & 1.24 & 3.74 & 1.87 & 0.15 & 0.08 & 5.84 & 0.05 & 5.89 & 99.15 & 13.87 & 52.48 \\
\hline $20-32$ & 7.7 & 0.48 & 0.07 & 0.83 & 4.81 & 3.07 & 0.07 & 0.04 & 7.99 & 0.05 & 8.04 & 99.38 & 28.70 & 24.31 \\
\hline $32-57$ & 8.5 & 0.45 & 0.07 & 0.78 & 8.01 & 6.14 & 0.08 & 0.04 & 14.27 & 0.05 & 14.32 & 99.65 & 0.40 & 29.67 \\
\hline $57-76$ & 8.2 & 0.41 & 0.06 & 0.71 & 10.68 & 8.41 & 0.10 & 0.06 & 19.25 & 0.03 & 19.28 & 99.84 & 0.48 & 35.29 \\
\hline $76-120 / 128$ & 8.2 & 0.31 & 0.05 & 0.53 & 18.16 & 11.35 & 0.19 & 0.08 & 29.78 & 0.05 & 29.83 & 99.83 & 0.48 & 70.13 \\
\hline
\end{tabular}

$\mathrm{OC}=$ Organic carbon, $\mathrm{OM}=$ Organic matter, TEB = Total exchangeable bases, $\mathrm{EA}=$ Exchangeable acidity, $\mathrm{CEC}=$ Cation exchange capacity, $\mathrm{BS}=\mathrm{Base}$ saturation. 
Table A2. Physical and hydraulic properties of soils in the Bongo and Vea irrigation schemes.

\begin{tabular}{|c|c|c|c|c|c|c|c|}
\hline $\begin{array}{c}\text { Morphological } \\
\text { Horizon }(\mathrm{cm})\end{array}$ & Soil Texture & $\begin{array}{l}\text { Bulk Density } \\
\left(\mathrm{g} \mathrm{cm}^{-3}\right)\end{array}$ & SAT (\%) & FC (\%) & PWP (\%) & TAW (\%) & $\begin{array}{c}\text { Ksat } \\
\left(\mathrm{mm} \mathrm{day}{ }^{-1}\right)\end{array}$ \\
\hline \multicolumn{8}{|c|}{ Pit 1 (Bongo irrigation scheme) } \\
\hline $0-12$ & Sandy loam & 1.10 & 49.7 & 16.9 & 6.2 & 10.6 & 1744 \\
\hline $12-30$ & Loamy sand & 1.27 & 47.5 & 19.1 & 4.3 & 14.9 & 1816 \\
\hline $30-56$ & Sandy loam & 1.26 & 45.8 & 19.1 & 5.8 & 13.3 & 1318 \\
\hline $56-75$ & Sandy loam & 1.28 & 46.7 & 14.1 & 4.2 & 9.9 & 1641 \\
\hline $75-100$ & Sandy loam & 1.36 & 45.2 & 18.3 & 6.4 & 11.9 & 1109 \\
\hline $100-125$ & Sandy loam & 1.44 & 44.2 & 17.8 & 6.3 & 11.6 & 885 \\
\hline \multicolumn{8}{|c|}{ Pit 2 (Bongo irrigation scheme) } \\
\hline $0-20$ & Silt loam & 1.07 & 51.5 & 34.2 & 11.0 & 23.2 & 632 \\
\hline $20-44$ & Loam & 1.32 & 44.6 & 31.1 & 12.6 & 18.5 & 363 \\
\hline $44-80$ & Loam & 1.53 & 45.1 & 40.7 & 18.7 & 22.0 & 261 \\
\hline $80-120$ & Loam & 1.40 & 45.7 & 44.2 & 14.8 & 29.4 & 192 \\
\hline \multicolumn{8}{|c|}{ Pit 3 (Vea irrigation scheme) } \\
\hline $0-20$ & Sandy loam & 1.37 & 47.3 & 20.3 & 5.4 & 14.9 & 1473 \\
\hline $20-32$ & Sandy loam & 1.59 & 45.3 & 22.0 & 8.8 & 13.2 & 625 \\
\hline $32-57$ & Loam & 1.57 & 45.1 & 32.9 & 14.8 & 18.1 & 226 \\
\hline $57-76$ & Loam & 1.56 & 47.0 & 38.6 & 14.0 & 24.6 & 159 \\
\hline $76-128$ & Clay loam & 1.52 & 49.7 & 47.3 & 17.5 & 29.8 & 86 \\
\hline
\end{tabular}

SAT $=$ Water content at saturation, $\mathrm{FC}=$ Field capacity, $\mathrm{PWP}=$ Permanent wilting point, TAW = Total available water, $\mathrm{K}_{\mathrm{sat}}=$ Saturated hydraulic conductivity determined from pedo-transfer functions.

\section{Appendix B}

Table A3. Summary of crop growth and yield parameters and details of their measurements for each study season.

\begin{tabular}{|c|c|c|c|}
\hline Parameter & Method of Data Collection & Frequency of Data Collection & Cropping Field (Figure 3) \\
\hline \multicolumn{4}{|c|}{ Maize, 2014 rainy season } \\
\hline $\begin{array}{l}\text { Above-ground } \\
\text { biomass }\end{array}$ & $\begin{array}{l}\text { Destructive biomass sampling along } \\
\text { a } 1 \mathrm{~m} \text { rod on three selected rows } \\
\text { Destructive biomass sampling in } \\
\text { two } 8 \mathrm{~m} \text { row sections at harvest }\end{array}$ & $\begin{array}{l}\text { Three times during the crop } \\
\text { reproduction stage at two weeks } \\
\text { interval, and once at harvest time }\end{array}$ & BF1, VF1, BNF1 \\
\hline Plant density & $\begin{array}{l}\text { Counting of total number of plants along } \\
\text { the } 1 \mathrm{~m} \text { rod on the three selected rows } \\
\text { Estimation of the sampling area }\end{array}$ & $\begin{array}{l}\text { Three times during the crop } \\
\text { reproduction stage at } \\
\text { two weeks interval }\end{array}$ & BF1, VF1, BNF1 \\
\hline Row spacing & $\begin{array}{l}\text { The average distance between two adjacent } \\
\text { rows at five random locations }\end{array}$ & $\begin{array}{l}\text { Once during the } \\
\text { reproduction stage }\end{array}$ & BF1, VF1, BNF1 \\
\hline $\begin{array}{l}\text { Maximum } \\
\text { rooting depth }\end{array}$ & $\begin{array}{l}\text { Manual excavations of at least } \\
\text { three plants per crop }\end{array}$ & Once at harvest time & BF1, VF1, BNF1 \\
\hline Crop yield & $\begin{array}{l}\text { Harvesting and weighing of total maize } \\
\text { grain yield from two } 8 \mathrm{~m} \text { row sections }\end{array}$ & Once at harvest time & $\mathrm{BF} 1, \mathrm{VF} 1, \mathrm{BNF} 1$ \\
\hline \multicolumn{4}{|c|}{ Tomato, 2014-2015 dry season } \\
\hline $\begin{array}{l}\text { Above-ground } \\
\text { biomass }\end{array}$ & $\begin{array}{l}\text { Destructive biomass sampling along } \\
\text { a } 1 \mathrm{~m} \text { rod on three selected rows } \\
\text { Destructive biomass sampling in } \\
\text { two } 8 \mathrm{~m} \text { row sections at harvest }\end{array}$ & $\begin{array}{l}\text { Four times during the vegetative } \\
\text { and reproduction stages, and once } \\
\text { at harvest time }\end{array}$ & BF1, BF6, VF1, BNF1 \\
\hline Plant density & $\begin{array}{l}\text { Counting of total number of plants along } \\
\text { the } 1 \mathrm{~m} \text { rod on the three selected rows } \\
\text { Estimation of the sampling area }\end{array}$ & $\begin{array}{l}\text { Four times during the vegetative } \\
\text { and reproduction stages }\end{array}$ & BF1, BF6, VF1, BNF1 \\
\hline Leaf area index & $\begin{array}{l}\text { Measurements with the SunScan probe } \\
\text { (SS1-UM-2.0) at five random locations }\end{array}$ & $\begin{array}{l}\text { Four times during the vegetative } \\
\text { and reproduction stages }\end{array}$ & BF1, BF6, VF1, BNF1 \\
\hline Row spacing & $\begin{array}{l}\text { The average distance between two adjacent } \\
\text { rows at five random locations }\end{array}$ & Once at harvest time & BF1, BF6, VF1, BNF1 \\
\hline $\begin{array}{l}\text { Maximum } \\
\text { rooting depth }\end{array}$ & $\begin{array}{l}\text { Manual excavations of at least } \\
\text { three plants per crop }\end{array}$ & Once at harvest time & $\mathrm{BF} 1, \mathrm{BF} 6, \mathrm{VF} 1$ \\
\hline Crop yield & $\begin{array}{l}\text { Harvesting and weighing of total tomato } \\
\text { fruits from two } 8 \mathrm{~m} \text { row sections }\end{array}$ & Once at harvest time & BF1, BF6 \\
\hline
\end{tabular}


Table A3. Cont.

\begin{tabular}{cccc}
\hline Parameter & Method of Data Collection & Tomato, 2015-2016 dry season & Cropping Field (Figure 3) \\
\hline $\begin{array}{c}\text { Above-ground } \\
\text { biomass }\end{array}$ & $\begin{array}{c}\text { Destructive biomass sampling along } \\
\text { a } 1 \text { m rod on three selected rows } \\
\text { Destructive biomass sampling in } \\
\text { two 8 m row sections at harvest }\end{array}$ & $\begin{array}{c}\text { Four times during the vegetative } \\
\text { and reproduction stages }\end{array}$ & BF1, BF6, VF1, BNF1 \\
\hline Plant density & $\begin{array}{c}\text { Counting of total number of plants along } \\
\text { the 1 m rod on the three selected rows } \\
\text { Estimation of the sampling area }\end{array}$ & $\begin{array}{c}\text { Four times during the vegetative } \\
\text { and reproduction stages }\end{array}$ & BF1, BF6, VF1, BNF1 \\
\hline $\begin{array}{c}\text { Row spacing } \\
\text { rooting depth }\end{array}$ & $\begin{array}{c}\text { The average distance between two adjacent } \\
\text { rows at five random locations }\end{array}$ & $\begin{array}{c}\text { Once during the } \\
\text { reproduction stage }\end{array}$ & BF1, BF6, VF1, BNF1 \\
\hline Crop yield & $\begin{array}{c}\text { Manual excavations of at least } \\
\text { three plants per crop } \\
\text { fruits from two 8 m row sections }\end{array}$ & Once at harvest time & BF1, BF6, VF1, BNF1 \\
\hline
\end{tabular}

\section{References}

1. Cook, K.H.; Vizy, E.K. Impact of climate change on mid-twenty-first century growing seasons in Africa. Clim. Dyn. 2012, 39, 2937-2955. [CrossRef]

2. Sylla, M.B.; Nikiema, P.M.; Gibba, P.; Kebe, I.; Klutse, N.A.B. Climate Change over West Africa: Recent Trends and Future Projections. In Adaptation to Climate Change and Variability in Rural West Africa; Springer: Cham, Switzerland, 2016; pp. 25-40.

3. Sanfo, S.; Barbier, B.; Dabiré, I.W.P.; Vlek, P.L.G.; Fonta, W.M.; Ibrahim, B.; Barry, B. Rainfall variability adaptation strategies: An ex-ante assessment of supplemental irrigation from farm ponds in southern Burkina Faso. Agric. Syst. 2017, 152, 80-89. [CrossRef]

4. McCartney, M.; Smakhtin, V. Water Storage in An Era of Climate Change: Addressing the Challenges of Increasing Rainfall Variability; International Water Management Institute Blue Paper; IWMI: Colombo, Sri Lanka, 2010; pp. 1-24. Available online: https://www.agriskmanagementforum.org/sites/agriskmanagementforum.org/ files/Documents /water\%20storage\%20in\%20era\%20of\%20climate\%20change\%20IWMI\%20Blue_Paper_ 2010-final.pdf (accessed on 20 November 2016).

5. Rockström, J.; Barron, J. Water productivity in rainfed systems: Overview of challenges and analysis of opportunities in water scarcity prone savannahs. Irrig. Sci. 2007, 25, 299-311. [CrossRef]

6. Adwubi, A.; Amegashie, B.K.; Agyare, W.A.; Tamene, L.; Odai, S.N.; Quansah, C.; Vlek, P. Assessing sediment inputs to small reservoirs in Upper East Region, Ghana. Lakes Reserv. Res. Manag. 2009, 14, 279-287. [CrossRef]

7. Kranjac-Berisavljevic, G.; Abdul-Ghanyu, S.; Gandaa, B.Z.; Abagale, F.K. Dry Spells Occurrence in Tamale, Northern Ghana-Review of Available Information. J. Disaster Res. 2014, 9, 468-474. [CrossRef]

8. Dzanku, F.M.; Jirström, M.; Marstorp, H. Yield Gap-Based Poverty Gaps in Rural Sub-Saharan Africa. World Dev. 2015, 67, 336-362. [CrossRef]

9. Folberth, C.; Yang, H.; Gaiser, T.; Abbaspour, K.C.; Schulin, R. Modeling maize yield responses to improvement in nutrient, water and cultivar inputs in sub-Saharan Africa. Agric. Syst. 2013, 119, 22-34. [CrossRef]

10. Vlek, P.L.G.; Khamzina, A.; Tamene, L. Land Degradation and the Sustainable Development Goals: Threats and Potential Remedies; CIAT Publication No. 440; International Center for Tropical Agriculture (CIAT): Nairobi, Kenya, 2017. Available online: http:/ /hdl.handle.net/10568/81313 (accessed on 9 May 2018).

11. Drechsel, P.; Gyiele, L.; Kunze, D.; Cofie, O. Population density, soil nutrient depletion, and economic growth in sub-Saharan Africa. Ecol. Econ. 2001, 38, 251-258. [CrossRef]

12. Vlek, P.L.G.; Khamzina, A.; Azadi, H.; Bhaduri, A.; Bharati, L.; Braimoh, A.; Martius, C.; Sunderland, T.; Taheri, F. Trade-offs in multi-purpose land use under land degradation. Sustainability 2017, 9, 2196. [CrossRef]

13. Henao, J.; Baanante, C. Agricultural Production and Soil Nutrient Mining in Africa: Implications for Resource Conservation and Policy Development; International Center for Soil Fertility and Agricultural Development: Muscle Shoals, AL, USA, 2006. 
14. Droogers, P.; Aerts, J. Adaptation strategies to climate change and climate variability: A comparative study between seven contrasting river basins. Phys. Chem. Earth Parts ABC 2005, 30, 339-346. [CrossRef]

15. Molden, D.; Oweis, T.; Steduto, P.; Bindraban, P.; Hanjra, M.A.; Kijne, J. Improving agricultural water productivity: Between optimism and caution. Agric. Water Manag. 2010, 97, 528-535. [CrossRef]

16. Mustapha, A.B. Effect of Dryspell Mitigation with Supplemental Irrigation on Yield and Water Use Efficiency of Pearl Millet in Dry Sub-Humid Agroecological Condition of Maiduguri. In Proceedings of the 2nd International Conference on Environment Science and Biotechnology; IACSIT Press: Singapore, 2012; pp. 46-49.

17. Zwart, S.J.; Bastiaanssen, W.G.M. Review of measured crop water productivity values for irrigated wheat, rice, cotton and maize. Agric. Water Manag. 2004, 69, 115-133. [CrossRef]

18. Ali, M.H.; Talukder, M.S.U. Increasing water productivity in crop production-A synthesis. Agric. Water Manag. 2008, 95, 1201-1213. [CrossRef]

19. Sekyi-Annan, E.; Tischbein, B.; Diekkrüger, B.; Khamzina, A. Performance evaluation of reservoir-based irrigation schemes in the Upper East region of Ghana. Agric. Water Manag. 2018, 202, 134-145. [CrossRef]

20. Pereira, L.S. Relating water productivity and crop evapotranspiration. Options Méditerr. Ser. B 2007, 57, 31-49.

21. Greaves, G.E.; Wang, Y.-M. Assessment of FAO AquaCrop Model for Simulating Maize Growth and Productivity under Deficit Irrigation in a Tropical Environment. Water 2016, 8, 557. [CrossRef]

22. Steduto, P.; Hsiao, T.C.; Fereres, E.; Reas, D. Crop Yield Response to Water; Food and Agriculture Organization of the United Nations: Rome, Italy, 2012. Available online: http:/ / www.fao.org/docrep/016/i2800e/i2800e.pdf (accessed on 13 November 2016).

23. Sekyi-Annan, E.; Acheampong, E.N.; Ozor, N. Modeling the Impact of Climate Variability on Crops in Sub-Saharan Africa. In Quantification of Climate Variability, Adaptation and Mitigation for Agricultural Sustainability; Springer International Publishing: Cham, Switzerland, 2017; pp. 39-70.

24. Gaydon, D.S.; Balwinder-Singh; Wang, E.; Poulton, P.L.; Ahmad, B.; Ahmed, F.; Akhter, S.; Ali, I.; Amarasingha, R.; Chaki, A.K.; et al. Evaluation of the APSIM model in cropping systems of Asia. Field Crops Res. 2017, 204, 52-75. [CrossRef]

25. Sommer, R.; Kienzler, K.; Christopher, C.; Ibragimov, N.; Lamers, J.; Martius, C.; Vlek, P. Evaluation of the CropSyst model for simulating the potential yield of cotton. Agron. Sustain. Dev. 2008, 28, 345-354. [CrossRef]

26. Fortes, P.S.; Teodoro, P.R.; Campos, A.A.; Mateus, P.M.; Pereira, L.S. Model tools for irrigation scheduling simulation: WINISAREG and GISAREG. In Irrigation Management for Combating Desertification in the Aral Sea Basin. Assessment and Tools; Vita Color Publication: Tashkent, Uzbekistan, 2005; pp. 81-96.

27. Jones, J.W.; Hoogenboom, G.; Porter, C.H.; Boote, K.J.; Batchelor, W.D.; Hunt, L.A.; Wilkens, P.W.; Singh, U.; Gijsman, A.J.; Ritchi, J.T. The DSSAT cropping system model. Eur. J. Agron. 2003, 18, 235-265. [CrossRef]

28. Surendran, U.; Sushanth, C.M.; Mammen, G.; Joseph, E.J. Modelling the Crop Water Requirement Using FAO-CROPWAT and Assessment of Water Resources for Sustainable Water Resource Management: A Case Study in Palakkad District of Humid Tropical Kerala, India. Aquat. Procedia 2015, 4, 1211-1219. [CrossRef]

29. Wang, X.C.; Li, J. Evaluation of crop yield and soil water estimates using the EPIC model for the Loess Plateau of China. Math. Comput. Model. 2010, 51, 1390-1397. [CrossRef]

30. Wellens, J.; Raes, D.; Traore, F.; Denis, A.; Djaby, B.; Tychon, B. Performance assessment of the FAO AquaCrop model for irrigated cabbage on farmer plots in a semi-arid environment. Agric. Water Manag. 2013, 127, 40-47. [CrossRef]

31. Walker, S.; Bello, Z.A.; Mabhaudhi, T.; Modi, A.T.; Beletse, Y.G.; Zuma-Netshiukhwi, G. Calibration of AquaCrop Model to predict water requirements of African vegetables. Acta Hortic. 2013, 1007, 943-949. [CrossRef]

32. Mabhaudhi, T.; Modi, A.T.; Beletse, Y.G. Parameterisation and evaluation of the FAO-AquaCrop model for a South African taro (Colocasia esculenta L. Schott) landrace. Agric. For. Meteorol. 2014, 192-193, 132-139. [CrossRef]

33. Faulkner, J.W.; Steenhuis, T.; van de Giesen, N.; Andreini, M.; Liebe, J.R. Water use and productivity of two small reservoir irrigation schemes in Ghana's upper east region. Irrig. Drain. 2008, 57, 151-163. [CrossRef]

34. Mdemu, M.V. Water Productivity in Medium and Small Reservoirs in the Upper East Region (UER) of Ghana. Ph.D. Thesis, University of Bonn, Bonn, Germany, 2008. Available online: http:/ /hss.ulb.uni-bonn.de/2008/ 1362/1362.pdf (accessed on 21 October 2016). 
35. Barry, B.; Forkuor, G. Contribution of Informal Shallow Groundwater Irrigation to Livelihoods Security and Poverty Reduction in the White Volta Basin (WVB): Current Status and Future Sustainability; International Water Management Institute: Colombo, Sri Lanka, 2010. Available online: https:/ / cgspace.cgiar.org/bitstream/ handle/10568/3940/PN65_IWMI_Project\%20Report_May10_final.pdf?sequence=1\&isAllowed=y (accessed on 22 February 2017).

36. Asres, S.B. Evaluating and enhancing irrigation water management in the upper Blue Nile basin, Ethiopia: The case of Koga large scale irrigation scheme. Agric. Water Manag. 2016, 170, 26-35. [CrossRef]

37. Fox, P.; Rockström, J. Supplemental irrigation for dry-spell mitigation of rainfed agriculture in the Sahel. Agric. Water Manag. 2003, 61, 29-50. [CrossRef]

38. Srivastava, A.K.; Mboh, C.M.; Gaiser, T.; Ewert, F. Impact of climatic variables on the spatial and temporal variability of crop yield and biomass gap in Sub-Saharan Africa-A case study in Central Ghana. Field Crops Res. 2017, 203, 33-46. [CrossRef]

39. Raes, D.; Steduto, P.; Hsiao, T.C.; Fereres, E. Chapter 2-Users guide. In Reference Manual: AquaCrop, Version 4.0; FAO, Land and Water Division: Rome, Italy, 2012; pp. 1-164.

40. Allen, R.G.; Pereira, L.S.; Raes, D.; Smith, M. Crop Evapotranspiration: Guidelines for Computing Crop Water Requirements; Food and Agricultural Organization of the United Nations: Rome, Italy, 1998. Available online: https://www.unirc.it/documentazione/materiale_didattico/1462_2016_412_24101.pdf (accessed on 15 November 2016).

41. Doorenbos, J.; Pruitt, W.O.; Aboukhaled, A.; Damagnez, J.; Dastane, N.G.; Van Den Berg, C.; Rijtema, P.E.; Ashford, O.M.; Frère, M. Crop Water Requirements; FAO Irrigation and Drainage Paper No. 24; Food and Agriculture Organization of the United Nations: Rome, Italy, 1992; pp. 70-72.

42. Amekudzi, L.; Yamba, E.; Preko, K.; Asare, E.; Aryee, J.; Baidu, M.; Codjoe, S. Variabilities in Rainfall Onset, Cessation and Length of Rainy Season for the Various Agro-Ecological Zones of Ghana. Climate 2015, 3, 416-434. [CrossRef]

43. Raes, D. Frequency Analysis of Rainfall Data; International Centre for Theoretical Physics (ICTP): Leuven, Belgium, 2004. Available online: http:/ /indico.ictp.it/event/a12165/session/21/contribution/16/material/ 0/0.pdf (accessed on 3 January 2017).

44. Mbah, C.N. Determining the field capacity, wilting point and available water capacity of some Southeast Nigerian soils using soil saturation from capillary rise. Niger. J. Biotechnol. 2012, 24, 41-47.

45. Pedescoll, A.; Samsó, R.; Romero, E.; Puigagut, J.; García, J. Reliability, repeatability and accuracy of the falling head method for hydraulic conductivity measurements under laboratory conditions. Ecol. Eng. 2011, 37, 754-757. [CrossRef]

46. Saxton, K.E.; Rawls, W.J. Soil Water Characteristic Estimates by Texture and Organic Matter for Hydrologic Solutions. Soil Sci. Soc. Am. J. 2006, 70, 1569-1578. [CrossRef]

47. Bell, M.A.; Fischer, R.A. Guide to Plant and Crops Sampling: Measurements and Observations for Agronomic and Physiological Research in Small Grain Cereals; CIMMYT: Mexico City, Mexico, 1994. Available online: http:/ /libcatalog.cimmyt.org/download/cim/53067.pdf (accessed on 11 November 2016).

48. Raes, D.; Steduto, P.; Hsiao, T.C.; Fereres, E. Chapter 3: Calculation procedures. In Reference Manual: AquaCrop, Version 4.0; FAO, Land and Water Division: Rome, Italy, 2012; pp. 1-130.

49. Adu-Dapaah, H.K.; Oppong-Konadu, E.Y. Tomato production in four major tomato-growing districts in Ghana: Farming practices and production constraints. Ghana J. Agric. Sci. 2002, 35, 11-22. [CrossRef]

50. Sallah, P.Y.K.; Twumasi-Afriyie, S.; Kasei, C. Optimum planting dates for four maturity groups of maize varieties grown in the Guinea savanna zone. Ghana J. Agric. Sci. 1997, 30, 63-69. [CrossRef]

51. Sugri, I.; Kanton, R.A.L.; Kusi, F.; Nutsugah, S.K.; Buah, S.S.J.; Zakaria, M. Influence of Current Seed Programme of Ghana on Maize (Zea mays) Seed Security. Res. J. Seed Sci. 2013, 6, 29-39. [CrossRef]

52. Bos, M.G.; Kselik, R.A.; Allen, R.G.; Molden, D. Capillary Rise. In Water Requirements for Irrigation and the Environment; Springer Netherlands: Dordrecht, The Netherlands, 2009; pp. 103-118.

(C) 2018 by the authors. Licensee MDPI, Basel, Switzerland. This article is an open access article distributed under the terms and conditions of the Creative Commons Attribution (CC BY) license (http:/ / creativecommons.org/licenses/by/4.0/). 